\title{
T-cell-based Immunotherapies for Haematological Cancers, Part A: A SWOT Analysis of Immune Checkpoint Inhibitors (ICIs) and Bispecific T-Cell Engagers (BiTEs)
}

\author{
KATHRINE S. RALLIS ${ }^{1,2}$, CHRISTOPHER R.T. HILLYAR ${ }^{2}$, MICHAIL SIDERIS ${ }^{3}$ and JEFF K. DAVIES ${ }^{1}$ \\ ${ }^{1}$ Barts Cancer Institute, Queen Mary University of London, London, U.K.; \\ ${ }^{2}$ Barts and The London School of Medicine and Dentistry, Queen Mary University of London, London, U.K.; \\ ${ }^{3}$ Women's Health Research Unit, Queen Mary University of London, London, U.K.
}

\begin{abstract}
Haematology has been at the vanguard of cancer immunotherapy. Immune checkpoint inhibitors (ICIs), bispecific T-cell engagers (BiTEs), allogeneic haematopoietic stem cell transplantation (allo-HSCT) and donor lymphocyte infusion (DLI), as well as adoptive T-cell therapies outside the setting of allo-HSCT, have been approved for distinct haematologic malignancies producing durable responses in otherwise untreatable patients. Despite recent advances, immunotherapies do not benefit most patients, due to resistance or lack of response, and are only approved in specific settings. Moreover, immunotherapies are expensive and may produce severe immune related adverse reactions. Combination therapy complicates the picture and requires further evaluation. This review considers the current status and future perspectives of ICIs and BiTEs approved for haematological malignancies by analysing their strengths, weaknesses, opportunities and threats (SWOT). The biological rationale for anti-cancer mechanisms, clinical data for specific haematological cancers, efficacy, toxicity, response and resistance profiles, novel strategies to improve these characteristics as well as the potential targets to enhance or expand the application of ICIs and BiTEs are also discussed.
\end{abstract}

This article is freely accessible online.

Correspondence to: Kathrine S. Rallis, MSc, Barts and The London School of Medicine and Dentistry, Turner Street, Whitechapel, London E1 2AD, U.K. Tel: +44 2078822239, e-mail: k.s.rallis@smd16.qmul.ac.uk

Key Words: Hematologic malignancies, $\mathrm{T}$ cells, T-cell immunotherapy, cancer immunotherapy, immune checkpoint inhibitors, ICI, checkpoint blockade, bispecific T-cell engagers, BiTEs, cancer treatment, review.
Cancer immunotherapy has revolutionised oncology care, prolonging survival in rapidly fatal diseases. The number of patients eligible for immune-based cancer treatments is increasing, with immunotherapies being adopted in first line setting (1). Novel targets and combination therapies are set to expand cancer immunotherapy applications. Haematology has been central to these advances.

Allogeneic haematopoietic stem cell transplantation (allo-HSCT) was the first clinical application of cancer immunotherapy (1957), while monoclonal antibodies $(\mathrm{mAb})$ were the next success story with the approval of rituximab (anti-CD20 $\mathrm{mAb}$ ) for B-cell malignancies (1997). These breakthroughs contributed valuable advances to the evolution of cancer immunotherapies. Immune checkpoint inhibitors, developed through mAbs, target T-cells and upregulate anticancer immunity, producing remarkable success in solid and haematologic malignancies. Bispecific T-cell engager (BiTE) antibodies, which redirect T-cells to tumour cells to perform target cell killing, were originally approved for B-cell precursor acute lymphoblastic leukaemia (BCP-ALL), with blinatumomab gaining approval in 2014. Development of novel adoptive T-cell (ATC) therapies in haematology, such as chimeric antigen receptor (CAR)-T-cells, has generated great interest with potential for disease cure.

Yet, despite these advances, several challenges remain. Limited breadth of application, unpredictable efficacy, and limiting toxicity profiles attest the need to drive forward change. This review discusses the strengths, weaknesses, opportunities and threats (SWOT) associated with immune checkpoint inhibitors (ICIs) and BiTEs, providing an up-to-date review of licensed agents for haematological malignancies. The biological rationale for anti-cancer mechanism; clinical data in specific haematological cancers; efficacy, toxicity, response and resistance profiles; novel strategies to improve these 
characteristics; and potential targets to enhance or expand the application of these agents are discussed.

\section{Immune Checkpoint Inhibitors}

Biological rationale for anti-cancer mechanism.

Immune checkpoints, compromising co-inhibitory and costimulatory co-signalling T-cell-receptor systems regulate Tcell activation (2) and ensure self-tolerance as per the twosignal hypothesis of T-cell activation (3-6) (Figure 1). Cancers upregulate inhibitory immune checkpoints within the tumour microenvironment (TME), supressing $\mathrm{CD}^{+}{ }^{+} \mathrm{T}$-cell response to tumour associated antigens (TAA) and evading immune destruction (7). Targeting inhibitory immune checkpoints restores anti-tumour immunity. Programmed cell death 1 (PD1) and cytotoxic T lymphocyte antigen 4 (CTLA-4, CD152), two functionally dominant T-cell immune checkpoint molecules, have demonstrated remarkable therapeutic potential (8). CTLA-4 and PD-1 co-inhibitory receptor systems belong to the B7-CD28 superfamily, the most potent T-cell cosignalling receptor immunoglobulin (Ig) family $(1,9)$.
Physiological role of CTLA-4 signalling and therapeutic targeting in cancer. CTLA-4 (CD152) is rapidly expressed following T-cell activation (10), countering the costimulation via CD28 which is constitutively expressed (1113). Two B7 ligand family members, B7-1/BB1 (CD80) (1417) and B7-2/B70 (CD86) (18-20), bind CD28 and CTLA4. CTLA-4 binds with 10-100 times higher affinity and avidity as it homodimerizes, binding B7 bivalently (21-24). Reduced T-cell proliferation and cytokine secretion results.

Other than competitive antagonism against CD28 (25), CTLA-4 exerts inhibitory effects through phosphatase activity at its cytoplasmic tail (Figure 2). CTLA-4 induces T-cell tolerance $(26,27)$ by inhibiting nuclear accumulation of activator protein 1 (AP-1), NF-kB, and nuclear factor of activated T-cells (NFAT) $(28,29)$; thus halting cell cycle progression of T-cells by directly inhibiting cyclin-dependent kinase 4 (CDK4), CDK6, and cyclin D3 (30), and selectively inactivating microtubule-associated protein kinase (MAPK), extracellular signal-regulated kinase-1 (ERK), and c-Jun $\mathrm{NH}_{2}$-terminal kinase $(\mathrm{JNK})$, which stimulate IL-2 production $(31,32)$.

\section{TWO SIGNALHYPOTHESIS}

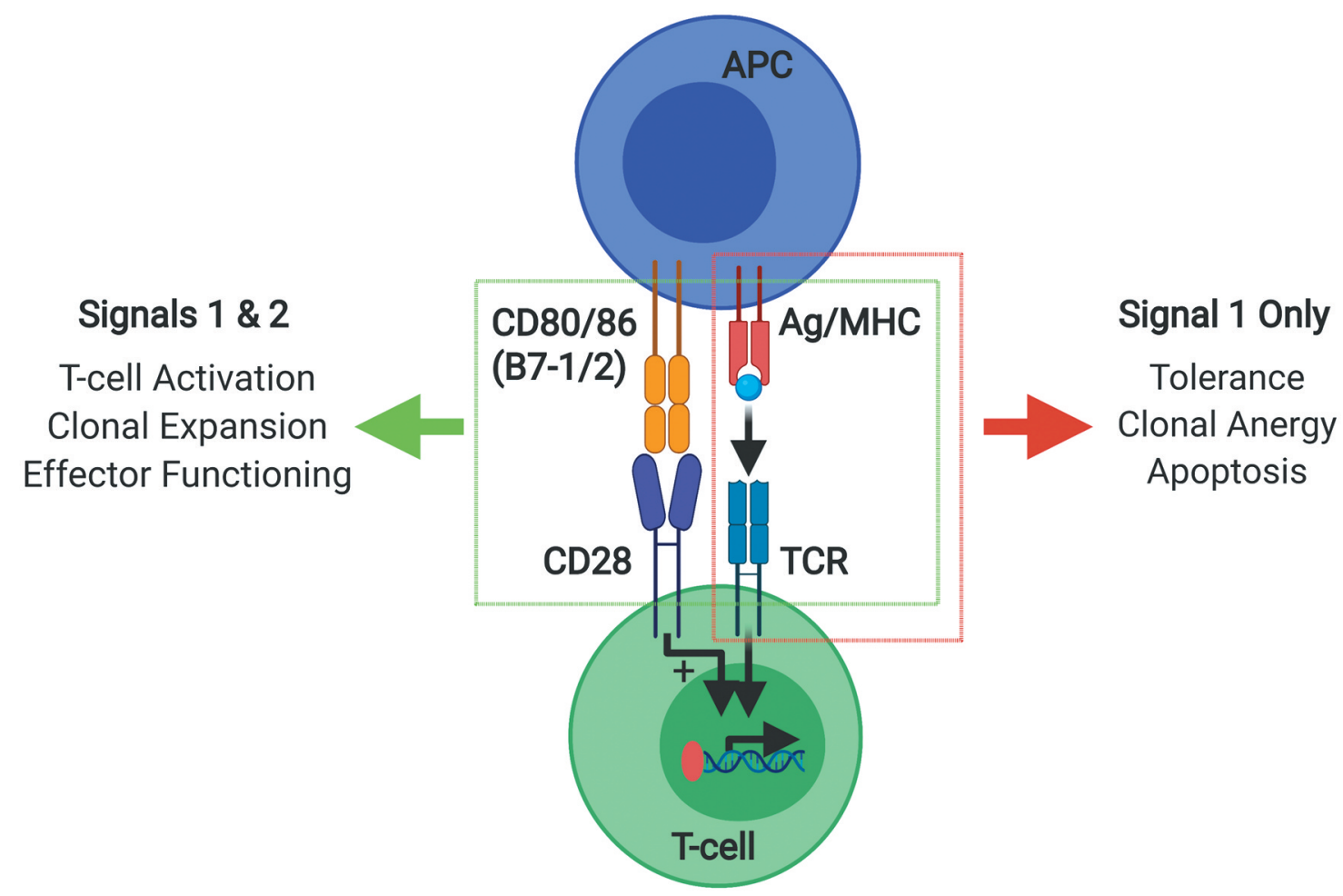

Figure 1. Two signal hypothesis for T-cell activation. Signal 1 is generated from the interaction of the T-cell receptor (TCR) with its antigen-major histocompatibility complex (ag/MHC) ligand on the antigen presenting cell (APC). Signal 2 is generated from an interaction between costimulatory molecules on the APC such as CD80 and CD86 with T-cell counter-receptors such as CD28. In the presence of only signal 1, T-cells undergo tolerance, anergy or apoptosis, whereas in the presence of both signals, T-cells undergo activation, clonal expansion and effector function. 


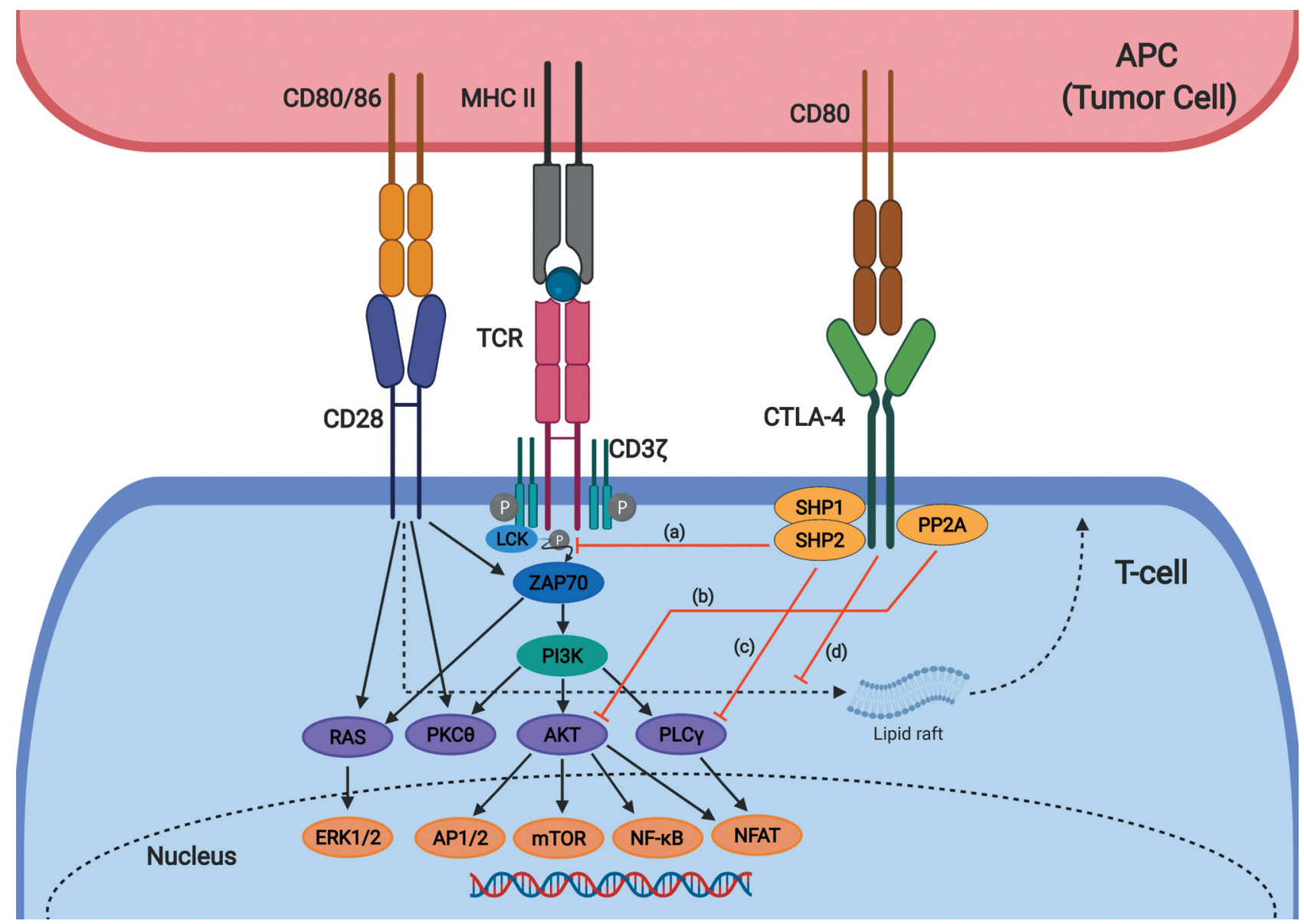

Figure 2. CTLA-4 signalling cascade. In resting T-cells, CTLA-4 is retained within secretory granules, however, upon T-cell-receptor (TCR) activation, CTLA-4 expression is upregulated on the T-cell plasma membrane and CTLA-4 binds to B7 ligands (CD80 and CD86) on antigen presenting cells (APCs) with 10- to 100-fold higher avidity and affinity than CD28. Ligation reduces T-cell proliferation and decreasing cytokine secretion through distinct mechanisms: a) direct antagonism of TCR signalling by recruitment of Src-homology 2 domain-containing phosphatase (SHP)-1 and SHP-2; b) PP2A-mediated inhibition of AKT and its downstream signalling cascade; c) SHP-2-mediated inhibition of PLC $\gamma$ and its downstream effector NFAT; and d) inhibition of CD28-mediated lipid raft formation.

Anti-CTLA-4 antibodies bind CTLA-4 inhibiting B7 ligation. Prolonged T-cell activation, restored T-cell proliferation, and amplified T-cell-mediated anti-tumour immunity result. High TAA burden predicts favourable response. In addition to boosting effector T cells, anti-CTLA4 therapy depletes local intra-tumoral regulatory T-cells (Tregs) through antibody-dependent T-cell-mediated cytotoxicity, thus shifting the TME from immunosuppression. The ratio of effector T-cells to tumour infiltrating Tregs predicts treatment outcome $(33,34)$.

Physiological role of PD-1 signalling and therapeutic targeting in cancer. PD-1 is another co-inhibitory receptor B7CD28 superfamily member (35) that interacts with PD-L1 (36) (B7-H1) (37) or PD-L2 (38) (B7-DC) (39), maintaining an exhausted T-cell phenotype (38). PD-1 ligands are constitutively expressed on antigen presenting cells (APCs). PD-1 expression is induced after T-cell receptor (TCR) stimulation, similarly to CTLA-4, and declines following inflammatory resolution (32). PD-1 acts locally within peripheral tissues whereas CTLA-4 acts within lymphoid organs (40). PD-1 acts later in T-cell activation than CTLA-4.

PD-1 regulates immune responses through inhibitory intracellular signalling in effector T-cells and Treg cells (41). Ligation induces phosphorylation of PD-1 cytoplasmic tails causing recruitment of phosphatase SHP1 and SHP2, which inactivate downstream effectors via dephosphorylation. These effectors are essential for T-cell activation (36) and CD28 signalling (42) (Figure 3) (43). PI3K-Akt-mTOR and Ras-MEK-ERK pathway activation is also inhibited via SHP2 independent mechanisms $(44,45)$; T-cell exhaustion or apoptosis results. 


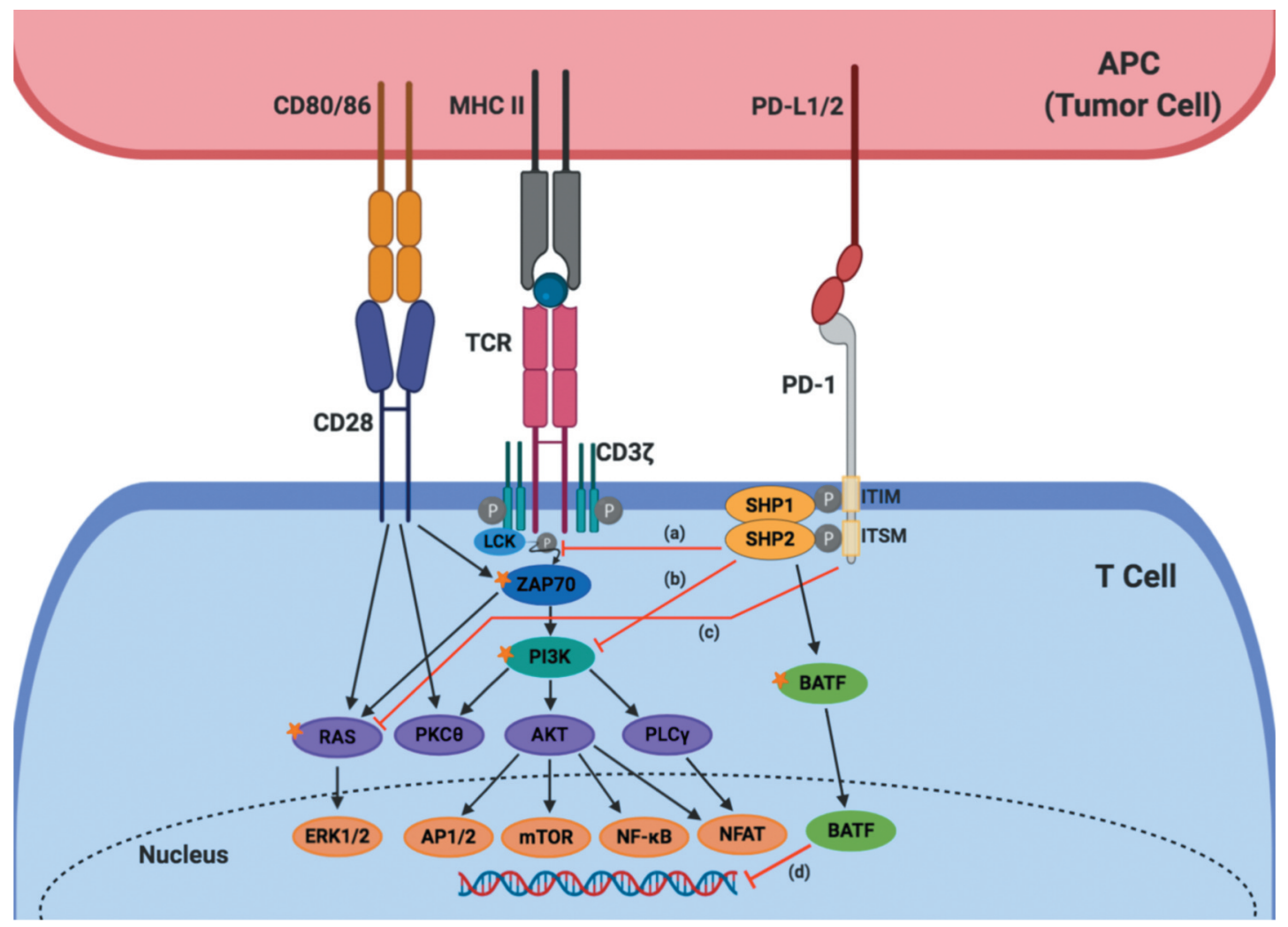

Figure 3. PD-1 signalling cascade. PD-1 expression on T-cells is upregulated following T-cell-receptor (TCR) engagement and activation similar to CTLA-4. The ligands, PD-L1 and PD-L2, are constitutively expressed on antigen presenting cells (APC). Ligation inhibits lymphocyte activation signals and inhibits T-cell function through distinct mechanisms: a) direct antagonism of TCR signalling occurs by recruitment of Src-homology 2 domain-containing phosphatase (SHP)-1 and SHP-2 to tyrosine-based inhibitory motifs (ITM; immunoreceptor tyrosine-based motifs) in the PD-1 tail; $b$ ) inhibition of metabolism, survival, nutrient sensing, cell growth and cell cycle progression occur via targeting of rapamycin (mTOR) pathway through PI3K/AKT inhibition; c) cell cycle arrest and reduced T-cell proliferation occur by Ras pathway inhibition; d) repressed expression of effector gene transcription occurs through increased expression of basic leucin zipper transcription factor and activating transcription factor (ATF)-like transcription factor (BATF). PD-1 signalling events also impair T-cell stability and motility, hindering the formation of immune synapses with APCs.

Anti-PD1 antibodies prevent PD-1 ligation and demonstrate broader utility than CTLA-4. PD-1 inhibition augments antitumour immunity and limits haematogenous seeding and metastasis (46). Increased PD-1 receptor and ligand expression in human cancers is a negative prognostic biomarker $(47,48)$, while PD-L1 expression in $>50 \%$ of tumour cells correlates to improved efficacy with PD-1 inhibitor pembrolizumab in non-small-cell lung cancer (NSCLC) (49). Anti-PD-L1 targets ligands instead of receptors.

\section{Clinical translation.}

The CTLA-4 inhibitor ipilimumab was the first ICI to be approved in 2011 for metastatic melanoma. Six ICIs have been approved since: PD-1 inhibitors nivolumab, pembrolizumab, cemiplimab and PD-L1 inhibitors atezolizumab, avelumab, and durvalumab (50). Nivolumab and pembrolizumab are licensed for specific Hodgkin's and non-Hodgkin lymphomas.

Nivolumab. In May 2016, nivolumab received accelerated FDA and European Medicines Agency (EMA) approval for relapsed or progressive classical Hodgkin's lymphoma (cHL) post-autologous stem cell transplantation and posttransplantation brentuximab vedotin (BV) therapy, an antiCD30 antibody-drug conjugate (ADC), or in pre-treated cHL after three therapies including autologous HSCT (51). Approval was based on pooled phase I and II (CheckMate039 and -205), single-arm, multicentre trial results $(52,53)$. A $65 \%$ overall response rate (ORR) with 8.7-month median duration was observed and 2.1-month median time to respond. Rare (1-5\%) immune-related adverse reactions (irARs) included rash, hyperthyroidism, pneumonitis, hepatitis, and colitis. Complications of allogeneic HSCT after nivolumab, including severe or hyperacute graft-versus- 
Rallis et al: ICIs and BiTEs for Haematological Cancers: A SWOT Analysis (Review)

Table I. Active clinical trials investigating nivolumab as treatment for lymphoid, plasma cell, myeloid, and mixed haematological malignancies.

\begin{tabular}{|c|c|c|c|c|}
\hline Malignancies & Clinical trial \# & Phase & Study description & Study name \\
\hline \multirow[t]{27}{*}{ Lymphoid neoplasm } & NCT02181738 & 2 & $\begin{array}{l}\text { Study of Nivolumab in Patients With Classical Hodgkin's Lymphoma } \\
\text { (Registrational) (CheckMate 205) }\end{array}$ & CheckMate 205 \\
\hline & NCT02857426 & 2 & $\begin{array}{l}\text { A Study of Nivolumab in Relapsed/Refractory Primary Central Nervous } \\
\text { System Lymphoma (PCNSL) and Relapsed/Refractory Primary Testicular } \\
\text { Lymphoma (PTL) }\end{array}$ & - \\
\hline & NCT03337919 & 2 & $\begin{array}{l}\text { ANIMATE: Phase II Study of Nivolumab Monotherapy for Relapsed/ } \\
\text { Refractory Hodgkin Lymphoma }\end{array}$ & ANIMATE \\
\hline & NCT03016871 & 2 & $\begin{array}{l}\text { Nivolumab, Ifosfamide, Carboplatin, and Etoposide as Second-Line Therapy } \\
\text { in Treating Patients With Refractory or Relapsed HL }\end{array}$ & - \\
\hline & NCT03620578 & 2 & $\begin{array}{l}\text { DA-EPOCH-R Induction Followed by Nivolumab Consolidation in Newly } \\
\text { Diagnosed MYC, BCL2 and/or BCL6 Rearranged HGBL }\end{array}$ & HO152 \\
\hline & NCT03436862 & 2 & $\begin{array}{l}\text { Nivolumab Maintenance Therapy After Autologous Stem Cell Transplant } \\
\text { in Hodgkin Lymphoma Patients at Relapse/Progression Risk }\end{array}$ & - \\
\hline & NCT04091490 & 2 & $\begin{array}{l}\text { Combination of Nivolumab and DHAP in Patients With Relapsed or } \\
\text { Refractory Classical Hodgkin Lymphoma (Nivo-DHAP) }\end{array}$ & - \\
\hline & NCT03258567 & 2 & $\begin{array}{l}\text { Nivolumab in Epstein-Barr Virus (EBV)-Positive Lymphoproliferative } \\
\text { Disorders and EBV-Positive Non-HodgkinLymphomas }\end{array}$ & - \\
\hline & NCT04401774 & 2 & $\begin{array}{l}\text { Nivolumab Maintenance in Newly Diagnosed PCNSL With Persistent CSF } \\
\text { Circulating Tumor DNA After Completion of First-Line Chemotherapy }\end{array}$ & - \\
\hline & NCT03586999 & $1-2$ & Nivolumab With Standard of Care Chemotherapy for Peripheral T Cell Lymphomas & - \\
\hline & NCT03311958 & 1 & Molecular Monitoring With Circulating Tumor DNA and Nivolumab Maintenance & - \\
\hline & NCT02973113 & 1 & $\begin{array}{l}\text { Nivolumab With Epstein Barr Virus Specific T Cells (EBVSTS), } \\
\text { Relapsed/Refractory EBV Positive Lymphoma (PREVALE) }\end{array}$ & PREVALE \\
\hline & NCT03927105 & 2 & $\begin{array}{l}\text { Nivolumab and the Antagonistic CSF-1R Monoclonal Antibody Cabiralizumab } \\
\text { (BMS-986227) in Patients With Relapsed/Refractory Peripheral T Cell Lymphoma }\end{array}$ & - \\
\hline & NCT03884998 & 1 & $\begin{array}{l}\text { Copanlisib and Nivolumab in Treating Participants With Richter's } \\
\text { Transformation or Transformed Indolent Non-Hodgkin's Lymphoma }\end{array}$ & - \\
\hline & NCT04431635 & 1 & $\begin{array}{l}\text { Dose De-escalation Study of the PI3k Alpha/Delta Inhibitor, Copanlisib Given } \\
\text { in Combination With the Immunotherapeutic Agents, Nivolumab and Rituximab } \\
\text { in Patients With Relapsed/Refractory Indolent Lymphoma }\end{array}$ & - \\
\hline & NCT03569696 & 2 & $\begin{array}{l}\text { Improving the Outcome of High-risk Aggressive B-cell Lymphoma Patients } \\
\text { With Nivolumab Maintenance Therapy }\end{array}$ & NivoM \\
\hline & NCT03480334 & 2 & $\begin{array}{l}\text { Abscopal Effect of Radiotherapy and Nivolumab in Relapsed Hodgkin } \\
\text { Lymphoma After Anti-PD1 Therapy }\end{array}$ & AERN \\
\hline & NCT03305445 & $1-2$ & Nivolumab/Ipilimumab-Primed Immunotransplant for DLBCL & - \\
\hline & NCT03892044 & 1 & $\begin{array}{l}\text { Duvelisib and Nivolumab in Treating Patients With Richter Syndrome or } \\
\text { Transformed Follicular Lymphoma }\end{array}$ & - \\
\hline & NCT03502733 & 1 & $\begin{array}{l}\text { Testing the Combination of Copanlisib, Nivolumab and Ipilimumab in } \\
\text { Patients With Advanced Cancer and Lymphoma }\end{array}$ & - \\
\hline & NCT02572167 & $1-2$ & $\begin{array}{l}\text { A Study of Brentuximab Vedotin Combined With Nivolumab for Relapsed } \\
\text { or Refractory Hodgkin Lymphoma }\end{array}$ & - \\
\hline & NCT03138499 & 3 & $\begin{array}{l}\text { A Study of Nivolumab Plus Brentuximab Vedotin Versus Brentuximab } \\
\text { Vedotin Alone in Patients With Advanced Stage Classical Hodgkin } \\
\text { Lymphoma, Who Are Relapsed/Refractory or Who Are Not Eligible } \\
\text { for Autologous Stem Cell Transplant }\end{array}$ & CheckMate 812 \\
\hline & NCT03245021 & 1 & Nivolumab Plus Rituximab in First-line Follicular Lymphoma gr 1-3A & $1 \mathrm{stFLOR}$ \\
\hline & NCT02857426 & 2 & $\begin{array}{l}\text { A Study of Nivolumab in Relapsed/Refractory Primary Central Nervous } \\
\text { System Lymphoma (PCNSL) and Relapsed/Refractory Primary Testicular } \\
\text { Lymphoma (PTL) }\end{array}$ & CheckMate 647 \\
\hline & NCT02581631 & $1-2$ & $\begin{array}{l}\text { An Investigational Immuno-therapy Safety and Effectiveness Study } \\
\text { of Nivolumab in Combination With Brentuximab Vedotin to Treat } \\
\text { Non-Hodgkin Lymphomas }\end{array}$ & CheckMate 436 \\
\hline & NCT03061188 & 1 & $\begin{array}{l}\text { Nivolumab and Veliparib in Treating Patients With Recurrent or } \\
\text { Refractory Stage IV Solid Tumors That Cannot Be Removed by } \\
\text { Surgery or Lymphoma With or Without Alterations in DNA Repair Genes }\end{array}$ & - \\
\hline & NCT03484819 & 2 & $\begin{array}{l}\text { Copanlisib Hydrochloride and Nivolumab in Treating Patients With } \\
\text { Recurrent or Refractory Diffuse Large B-cell Lymphoma or Primary } \\
\text { Mediastinal Large B-cell Lymphoma }\end{array}$ & - \\
\hline
\end{tabular}


Table I. Continued

\begin{tabular}{|c|c|c|c|c|}
\hline Malignancies & Clinical trial \# & Phase & Study description & Study name \\
\hline & NCT03704714 & $1-2$ & $\begin{array}{l}\text { Nivolumab and Combination Chemotherapy in Treating Participants } \\
\text { With Diffuse Large B-Cell Lymphoma }\end{array}$ & \\
\hline & NCT02038946 & 2 & $\begin{array}{l}\text { Study of Nivolumab in Subjects With Relapsed or Refractory } \\
\text { Follicular Lymphoma (FL) (CheckMate 140) }\end{array}$ & CheckMate 140 \\
\hline & NCT03580408 & 2 & $\begin{array}{l}\text { Study Of Nivolumab Alone, Or In Combination With Vinblastin } \\
\text { In Patients With Classical Hodgkin Lymphoma }\end{array}$ & - \\
\hline & NCT02940301 & 2 & $\begin{array}{l}\text { Ibrutinib and Nivolumab in Treating Patients With Relapsed or } \\
\text { Refractory Classical Hodgkin Lymphoma }\end{array}$ & - \\
\hline & NCT03703050 & 2 & $\begin{array}{l}\text { Nivolumab for Pediatric and Adult Relapsing/Refractory ALK+ Anaplastic } \\
\text { Large Cell Lymphoma, for Evaluation of Response in Patients With } \\
\text { Progressive Disease (Cohort 1) or as Consolidative Immunotherapy } \\
\text { in Patients in Complete Remission After Relapse (Cohort 2) }\end{array}$ & NIVO-ALCL \\
\hline & NCT03920631 & 1 & $\begin{array}{l}\text { Microtransplantation and Checkpoint Blockade Immunotherapy } \\
\text { for Relapsed or Refractory B Cell Lymphomas }\end{array}$ & MicroBLITZ \\
\hline & NCT03770416 & 2 & $\begin{array}{l}\text { Nivolumab and Ibrutinib in Treating Patients With Relapsed or } \\
\text { Refractory Central Nervous System Lymphoma }\end{array}$ & - \\
\hline & NCT03843294 & 1 & $\begin{array}{l}\text { Tumor Associated Antigen Specific T Cells (TAA-T) } \\
\text { With PD1 Inhibitor for Lymphoma }\end{array}$ & - \\
\hline & NCT02927769 & 2 & $\begin{array}{l}\text { A Study of Nivolumab Plus Brentuximab Vedotin in Patients Between } \\
5 \text { and } 30 \text { Years Old, With Hodgkin's Lymphoma (cHL), Relapsed or } \\
\text { Refractory From First Line Treatment }\end{array}$ & CheckMate 744 \\
\hline & NCT02397720 & 1 & $\begin{array}{l}\text { Nivolumab and Azacitidine With or Without Ipilimumab in Treating } \\
\text { Patients With Refractory/Relapsed or Newly Diagnosed Acute } \\
\text { Myeloid Leukemia }\end{array}$ & - \\
\hline & NCT02181738 & 2 & $\begin{array}{l}\text { Study of Nivolumab in Patients With Classical Hodgkin's } \\
\text { Lymphoma (Registrational) }\end{array}$ & CheckMate 205 \\
\hline & NCT03121677 & 1 & $\begin{array}{l}\text { Personalized Tumor Vaccine Strategy and PD-1 Blockade in Patients } \\
\text { With Follicular Lymphoma }\end{array}$ & - \\
\hline & NCT04134325 & 1 & $\begin{array}{l}\text { Study of PD-1 Inhibitors After CD30.CAR T Cell Therapy in } \\
\text { Relapsed/Refractory Hodgkin Lymphoma }\end{array}$ & - \\
\hline & NCT01716806 & 2 & $\begin{array}{l}\text { A Study of Brentuximab Vedotin With Hodgkin Lymphoma (HL) } \\
\text { and CD30-expressing Peripheral T-cell Lymphoma (PTCL) }\end{array}$ & - \\
\hline & NCT03057795 & 2 & $\begin{array}{l}\text { After Stem Cell Transplant in Treating Patients With Relapsed or } \\
\text { Refractory High-Risk Classical Hodgkin Lymphoma }\end{array}$ & - \\
\hline & NCT03749018 & 2 & $\begin{array}{l}\text { Nivolumab With DA-REPOCH Chemotherapy Regimen in Treating } \\
\text { Patients With Aggressive B-Cell Non-Hodgkin's Lymphoma Vedotin, }\end{array}$ & - \\
\hline & NCT03233347 & 2 & $\begin{array}{l}\text { Doxorubicin Hydrochloride, Vinblastine, Dacarbazine, Brentuximab } \\
\text { and Nivolumab in Treating Patients With Stage I-II Hodgkin Lymphoma }\end{array}$ & - \\
\hline & NCT03004833 & 2 & Nivolumab and AVD in Early-stage Unfavorable Classical Hodgkin Lymphoma & - \\
\hline & NCT03585465 & $1-2$ & $\begin{array}{l}\text { Nivolumab in Combination With Metronomic Chemotherapy in } \\
\text { Paediatrics Refractory/Relapsing Solid Tumors or Lymphoma }\end{array}$ & - \\
\hline & NCT01896999 & $1-2$ & $\begin{array}{l}\text { Brentuximab Vedotin and Nivolumab With or Without Ipilimumab } \\
\text { in Treating Patients With Relapsed or Refractory Hodgkin Lymphoma }\end{array}$ & - \\
\hline & NCT03033914 & $1-2$ & $\begin{array}{l}\text { A(B)VD Followed by Nivolumab as Frontline Therapy for Higher } \\
\text { Risk Patients With Classical Hodgkin Lymphoma (HL) }\end{array}$ & - \\
\hline & NCT03907488 & 3 & $\begin{array}{l}\text { Immunotherapy (Nivolumab or Brentuximab Vedotin) Plus } \\
\text { Combination Chemotherapy in Treating Patients With Newly } \\
\text { Diagnosed Stage III-IV Classic Hodgkin Lymphoma }\end{array}$ & - \\
\hline & NCT03004833 & 2 & Nivolumab and AVD in Early-stage Unfavorable Classical Hodgkin Lymphoma & - \\
\hline \multirow[t]{4}{*}{$\begin{array}{l}\text { Plasma cell } \\
\text { neoplasm }\end{array}$} & NCT01592370 & 1 & $\begin{array}{l}\text { An Investigational Immuno-Therapy Study to Determine the Safety } \\
\text { and Effectiveness of Nivolumab and Daratumumab in Patients } \\
\text { With Multiple Myeloma }\end{array}$ & - \\
\hline & NCT02726581 & 3 & $\begin{array}{l}\text { An Investigational Immuno-therapy Study of Nivolumab, Pomalidomide } \\
\text { and Dexamethasone Combinations in Patients With Multiple Myeloma }\end{array}$ & CheckMate 602 \\
\hline & NCT03782064 & 2 & $\begin{array}{l}\text { Dendritic Cell (DC)/Myeloma Fusions in Combination With } \\
\text { Nivolumab in Patients With Relapsed Multiple Myeloma }\end{array}$ & - \\
\hline & NCT01592370 & $1-2$ & $\begin{array}{l}\text { An Investigational Immuno-Therapy Study to Determine the Safety } \\
\text { and Effectiveness of Nivolumab and Daratumumab in Patients } \\
\text { With Multiple Myeloma }\end{array}$ & - \\
\hline
\end{tabular}


Table I. Continued

\begin{tabular}{|c|c|c|c|c|}
\hline Malignancies & Clinical trial \# & Phase & Study description & Study name \\
\hline & NCT02726581 & 3 & $\begin{array}{l}\text { An Investigational Immuno-therapy Study of Nivolumab, Pomalidomide } \\
\text { and Dexamethasone Combinations in Patients With Multiple Myeloma }\end{array}$ & CheckMate 602 \\
\hline & NCT03634800 & 2 & Radiotherapy With Immunotherapy for Systemic Effect in Myeloma (RISE-M) & RISE-M \\
\hline & NCT02719613 & 2 & $\begin{array}{l}\text { Continuing Treatment for Participants Who Have Participated in a Prior } \\
\text { Protocol Investigating Elotuzumab }\end{array}$ & - \\
\hline \multirow[t]{14}{*}{ Myeloid neoplasms } & NCT02530463 & 2 & $\begin{array}{l}\text { Nivolumab and/or Ipilimumab With or Without Azacitidine in Treating } \\
\text { Patients With Myelodysplastic Syndrome }\end{array}$ & - \\
\hline & NCT02275533 & 2 & $\begin{array}{l}\text { Nivolumab in Eliminating Minimal Residual Disease and Preventing Relapse } \\
\text { in Patients With Acute Myeloid Leukemia in Remission After Chemotherapy }\end{array}$ & - \\
\hline & NCT03184194 & 2 & $\begin{array}{l}\text { Nivolumab Combined With Daratumumab With or Without } \\
\text { Low-dose Cyclophosphamide }\end{array}$ & - \\
\hline & NCT03600155 & 1 & $\begin{array}{l}\text { Nivolumab and Ipilimumab After Donor Stem Cell Transplant in Treating } \\
\text { Patients With High Risk Refractory or Relapsed Acute Myeloid Leukemia } \\
\text { or Myelodysplastic Syndrome }\end{array}$ & - \\
\hline & NCT03681561 & $1-2$ & Nivolumab With Ruxolitinib in Relapsed or Refractory Classical Hodgkin Lymphoma & a \\
\hline & NCT02275533 & 2 & $\begin{array}{l}\text { Nivolumab in Eliminating Minimal Residual Disease and Preventing Relapse } \\
\text { in Patients With Acute Myeloid Leukemia in Remission After Chemotherapy }\end{array}$ & - \\
\hline & NCT02397720 & 2 & $\begin{array}{l}\text { Nivolumab and Azacitidine With or Without Ipilimumab in Treating Patients } \\
\text { With Refractory/Relapsed or Newly Diagnosed Acute Myeloid Leukemia }\end{array}$ & - \\
\hline & NCT03358719 & 1 & $\begin{array}{l}\text { DEC-205/NY-ESO-1 Fusion Protein CDX-1401, Poly ICLC, Decitabine, and } \\
\text { Nivolumab in Treating Patients With Myelodysplastic Syndrome or Acute } \\
\text { Myeloid Leukemia }\end{array}$ & - \\
\hline & NCT03092674 & $2-3$ & $\begin{array}{l}\text { Azacitidine With or Without Nivolumab or Midostaurin, or Decitabine and } \\
\text { Cytarabine Alone in Treating Older Patients With Newly Diagnosed Acute } \\
\text { Myeloid Leukemia or High-Risk Myelodysplastic Syndrome }\end{array}$ & - \\
\hline & NCT02530463 & 2 & $\begin{array}{l}\text { Nivolumab and/or Ipilimumab With or Without Azacitidine in Treating } \\
\text { Patients With Myelodysplastic Syndrome }\end{array}$ & - \\
\hline & NCT03292263 & $1-2$ & ASCT With Nivolumab in Patients With Multiple Myeloma & - \\
\hline & NCT03825367 & $1-2$ & $\begin{array}{l}\text { Nivolumab in Combination With 5-azacytidine in Childhood } \\
\text { Relapsed/Refractory AML }\end{array}$ & - \\
\hline & NCT04361058 & 1 & $\begin{array}{l}\text { Nivolumab for High-Risk MDS/AML Patients After Allogeneic Stem } \\
\text { Cell Transplant With Post-Transplant Cyclophosphamide }\end{array}$ & - \\
\hline & NCT02846376 & 1 & Single Agent and Combined Inhibition After Allogeneic Stem Cell Transplant & - \\
\hline \multirow{11}{*}{$\begin{array}{l}\text { Mixed } \\
\text { haematological } \\
\text { malignancies }\end{array}$} & NCT03146468 & 2 & $\begin{array}{l}\text { Nivolumab for Relapsed or Residual Haematological Malignancies After } \\
\text { Allogeneic Stem Cell Transplantation }\end{array}$ & - \\
\hline & NCT02681302 & $1-2$ & $\begin{array}{l}\text { Check Point Inhibition After Autologous Stem Cell Transplantation in Patients } \\
\text { at High Risk of Post Transplant Recurrence }\end{array}$ & - \\
\hline & NCT02663518 & 1 & $\begin{array}{l}\text { A Trial of TTI- } 621 \text { for Patients With Hematologic Malignancies and } \\
\text { Selected Solid Tumors }\end{array}$ & - \\
\hline & NCT02693535 & 2 & $\begin{array}{l}\text { TAPUR: Testing the Use of Food and Drug Administration (FDA) Approved } \\
\text { Drugs That Target a Specific Abnormality in a Tumor Gene in People With } \\
\text { Advanced Stage Cancer }\end{array}$ & TAPUR \\
\hline & NCT02978625 & 2 & $\begin{array}{l}\text { Talimogene Laherparepvec and Nivolumab in Treating Patients With Refractory } \\
\text { Lymphomas or Advanced or Refractory Non-melanoma Skin Cancers }\end{array}$ & - \\
\hline & NCT02304458 & $1-2$ & $\begin{array}{l}\text { Nivolumab With or Without Ipilimumab in Treating Younger Patients With } \\
\text { Recurrent or Refractory Solid Tumors or Sarcomas }\end{array}$ & - \\
\hline & NCT02758717 & 2 & $\begin{array}{l}\text { Nivolumab and Brentuximab Vedotin in Treating Older Patients With } \\
\text { Untreated Hodgkin Lymphoma }\end{array}$ & - \\
\hline & NCT03739619 & $1-2$ & $\begin{array}{l}\text { Gemcitabine, Bendamustine, and Nivolumab in Patients With Relapsed } \\
\text { or Refractory Classical Hodgkin Lymphoma }\end{array}$ & - \\
\hline & NCT01822509 & 1 & $\begin{array}{l}\text { Ipilimumab or Nivolumab in Treating Patients With Relapsed Hematologic } \\
\text { Malignancies After Donor Stem Cell Transplant }\end{array}$ & - \\
\hline & NCT02420912 & 2 & $\begin{array}{l}\text { Nivolumab and Ibrutinib in Treating Patients With Relapsed, Refractory, } \\
\text { or High-Risk Untreated Chronic Lymphocytic Leukemia, Small Lymphocytic } \\
\text { Lymphoma, or Richter Transformation }\end{array}$ & - \\
\hline & NCT02329847 & $1-2$ & $\begin{array}{l}\text { A Study to Evaluate Safety, Pharmacokinetics, Pharmacodynamics and } \\
\text { Preliminary Efficacy of the Combination of Ibrutinib With Nivolumab in } \\
\text { Participants With Hematologic Malignancies }\end{array}$ & - \\
\hline
\end{tabular}


Table I. Continued

\begin{tabular}{|c|c|c|c|c|}
\hline Malignancies & Clinical trial \# & Phase & Study description & Study name \\
\hline & NCT03712202 & 2 & $\begin{array}{l}\text { Brentuximab Vedotin and Nivolumab in Treating Patients With Early } \\
\text { Stage Classic Hodgkin Lymphoma }\end{array}$ & - \\
\hline & NCT03038672 & 2 & $\begin{array}{l}\text { Nivolumab With or Without Varlilumab in Treating Patients With Relapsed } \\
\text { or Refractory Aggressive B-cell Lymphomas }\end{array}$ & - \\
\hline & NCT03015896 & $1-2$ & $\begin{array}{l}\text { Nivolumab and Lenalidomide in Treating Patients With Relapsed or } \\
\text { Refractory Non-Hodgkin or Hodgkin Lymphoma }\end{array}$ & - \\
\hline & NCT04439214 & 2 & $\begin{array}{l}\text { Testing Nivolumab as a Potential Targeted Treatment in Cancers With } \\
\text { Mismatch Repair Deficiency (MATCH-Subprotocol Z1D) }\end{array}$ & $\begin{array}{c}\text { MATCH- } \\
\text { Subprotocol } \\
\text { Z1D }\end{array}$ \\
\hline & NCT04205409 & 2 & $\begin{array}{l}\text { Nivolumab for Relapsed, Refractory, or Detectable Disease Post Chimeric } \\
\text { Antigen Receptor T-cell Treatment in Patients With Hematologic Malignancies }\end{array}$ & - \\
\hline
\end{tabular}

HGBL, High grade B-cell lymphoma; EBV, Epstein-Bar virus; EBVSTS, Epstein-Bar virus specific T cells; DLBCL, diffuse large B-cell lymphoma; PTL, primary testicular lymphoma; FL, follicular lymphoma; TAA-T, tumour associated antigen-specific T-cells; HL, Hodgkin lymphoma; cHL, classical Hodgkin lymphoma; PTCL, peripheral T-cell lymphoma; DC, dendritic cell; FDA, Food and Drug Administration.

host disease (GVHD) and transplant-related mortality, caused a Warning and Precaution to be issued (51). Phase I-III trials investigating nivolumab for treatment of lymphoid, plasma cell, myeloid, and mixed haematological malignancies are shown in Table I.

Pembrolizumab. In 2017, pembrolizumab was granted accelerated approval for adults and children with relapsed or refractory $(\mathrm{R} / \mathrm{R}) \mathrm{cHL}$ after three prior therapies (54). The nonrandomized, single-arm, phase II, open-label trial (KEYNOTE-087) demonstrated $22 \%$ complete response (CR) and $47 \%$ partial response (PR) rate of 11.1 months median duration (55). Few patients (5\%) discontinued treatment due to ARs, and others (26\%) stopped treatment temporarily.

In 2018, approval was expanded to non-Hodgkin lymphoma (NHL), specifically primary mediastinal large Bcell lymphoma (PMBCL), a subtype of diffuse large B-cell lymphoma (DLBCL) following the phase IB and phase II, KEYNOTE-013 and -170 studies (56). ORRs of $48 \%$ and $45 \%$ were observed, with duration of response (DOR) not reached at 29.1 months and 12.5 months median follow-up duration in KEYNOTE-013 and -170, respectively. No CR patients in KEYNOTE-170 had relapsed at data cut-off; median PFS 5.5 months. Grade 3-4 ARs (23\%) included neutropenia; $11 \%$ experienced irARs including grade 4 pneumonitis (2\%). Active clinical trials investigating PD-1 inhibitors are ongoing (57).

\section{Strengths of ICIs.}

Responses in heavily pre-treated/resistant disease. As with other immunotherapies, a major advantage of ICIs is their ability to achieve a response in heavily pre-treated relapsed or refractory patients which is a testament to their therapeutic potency. Indeed, Marjanska et al. demonstrate the efficacy of nivolumab in heavily pre-treated paediatric patients including one patient with stage IV cHL who achieved CR with no significant ARs (58). Among patients with platinumrefractory, recurrent squamous-cell carcinoma of the head and neck, nivolumab produced longer OS and resulted in longer overall survival than treatment with standard, singleagent therapy (methotrexate, docetaxel, or cetuximab) (59).

Durable response. A hallmark of cancer immunotherapy is the durability of response that translates into clinical benefit (60). ICIs can potentially sustain the anti-tumour immune response indefinitely (61) due to T-cell immunologic memory (62-64).

Relatively well-tolerated. ICIs are tolerated better than chemotherapeutics and do not induce severe myelosuppression or sepsis, thus improving quality-of-life.

\section{Weaknesses of ICIs.}

Rare but severe toxicities. Autoimmune neurotoxicity, cardiotoxicity, pneumotoxicity, hepatoxicity, colitis, and endocrine toxicity may warrant ICI treatment discontinuation. Rarely, irARs can cause prolonged disability, be life-threatening, or fatal. Examples include progressive neuropathies, such as Guillain Barre syndrome, aseptic meningitis/encephalitis, and neuromuscular conditions, such as myasthenia gravis (1-2\%) (65).

Slow response, pseudoprogression, and hyperprogression. ICIs demonstrate different patterns of kinetics and disease progression to chemotherapeutics, producing an initial "tumour flare" termed pseudoprogression. Pseudoprogression $(\sim 10 \%)$ is a radiologically observed increase in tumour size due to T-cell infiltration, mimicking progressive disease (PD), though remission follows.

Pseudoprogression challenges clinical decision making. Immune-specific related response criteria have been developed (66). These define PD differently, allowing for treatment 
beyond initial progression, thus avoiding inappropriate early treatment discontinuation indicated by conventional Response Evaluation Criteria in Solid Tumours (RECIST).

Hyperprogression describes rapid PD after immunotherapy, corresponding to tumour growth and reduced survival. Hyperprogression is observed in 4-29\% of ICI-treated solid tumours (67). Predictive markers for progression, hyperprogression and pseudoprogression are needed.

Limited response and associated resistance: Most ICItreated patients fail to respond (60). Even patients with similar tumour biomarkers respond differently. Single-agent PD-1 blockade response in unselected patients is $\sim 40-70 \%$ in some diseases and $10-25 \%$ in others (61). cHL demonstrates high ICI response rates, with $65-87 \%$ ORR (68).

Aside from primary resistance, adaptive and acquired resistance may emerge. Acquired resistance rates vary between tumours. In cHL acquired resistance rates range between $19-57 \%$ in studies [reviewed in (61)]. An inverse relationship between PD-1 therapy ORR and acquired resistance indicates disease-specific acquired resistance mechanisms, through this association is absent in cHL (61).

Opportunities for ICIs.

New targets. Aside from B7-CD28, other potent immune receptor co-signalling superfamilies include tumour necrosis factor receptor (TNFR), T-cell immunoglobulin domain and mucin domain (TIM), poliovirus receptor (PVR)-like proteins, semaphorins, and butyrophilin (BTN)-like molecules (69). Within these, noteworthy targets include lymphocyte activation gene-3 (LAG-3, CD223), T-cell immunoglobulin and mucin domain-containing protein-3 (TIM-3), T-cell immunoreceptor with immunoglobulin and ITIM domains (TIGIT), or B- and T-lymphocyte attenuator (BTLA) (57).

Resistance mechanisms and response prediction. In HL, primary ICI resistance mechanisms include: $\mathrm{CD}^{+} \mathrm{T}$-cell exclusion and increased Tregs within the TME; insufficient T-cell activation by lack of antigen presentation; upregulated indoleamine 2,3-dioxygenase (IDO) metabolism; and augmented immunosuppression via tumour-associated macrophages (TAMs) or natural killer (NK) cells. Acquired resistance occurs via PD-1, LAG-3 and TIM upregulation following anti-PD-1 therapy and increased adenosine levels, though this may present in primary resistance $(68,70)$. IDO, LAG-3 and TIM inhibitors are being investigated in solid tumours as a means to overcome resistance (71-73). Potential ICI response prediction biomarkers correlating to resistance mechanisms have been identified in solid tumours $(74,75)$. High tumour mutation burden and PD-L1 expression have been shown to be independent predictors of ICI efficacy in various solid cancers according to one meta-analysis (76). Another meta-analysis showed that EGFR mutations are a negative predictor of ICI efficacy in NSCLC (77), while a single-centre study showed that KRAS mutations predict superior response to immunotherapy in NSCLC (78). Differential tumour infiltrating lymphocyte density in metastatic and primary tumour sites could also contribute to ICI response prediction according to one case report (79). PD-L1/2 expression is potentially a novel prognostic predictor according to a recent study (80).

ICI combination therapy with other immunotherapies. Combination therapy decreases resistance rates and improves efficacy. In HL, ipilimumab plus nivolumab demonstrated $74 \%$ ORR (81) while this concurrent combination has also demonstrated rapid and deep tumour regression in advanced melanoma with manageable safety profile (82). Combination therapy may enhance the efficacy of developing agents. PDL1/PD-1 blockade with CD33/CD3 BiTE enhanced T-cell proliferation and IFN- $\gamma$ production (83). Benefits are also demonstrated with CAR-T cells.

ICI combination therapy with chemotherapy. Chemotherapies alter the TME, which is important when considering adjunct ICIs, along with timings, dose, and administration sequence. Preclinically, chemotherapies are immunostimulatory, by immunosuppressive cell inhibition, effector cell activation, or increased immunogenicity by enhanced T-cell infiltration (84). Clinical results of anti-PD1/PD-L1 antibodies plus chemotherapy in advanced or metastatic non-squamous NSCLC support this combination as first-line therapy (85-87). In HL, nivolumab followed by adriamycin, bleomycin, vinblastine, and dacarbazine (ABVD) is being investigated (88). Pembrolizumab plus cytarabine in AML demonstrated 35\% CR and 56\% minimal residual disease (MRD)-negative remission (89).

ICI combination therapy with targeted therapies. In HL, nivolumab plus BV produced $82 \%$ ORR and $61 \%$ CR as firstline salvage therapy (90) while nivolumab, ipilimumab, and BV yielded $82 \%$ ORR and 68\% CR (91). Hypomethylating agents (HMAs), increased PD-L1, PD-L2, PD-1, and CTLA-4 expression in haematologic cancer patients, indicating that immune checkpoint pathways may mediate HMA resistance (92). HMAs induced PD-1 promoter demethylation, upregulating PD-1 expression on T-cells which promoted tumour-specific T-cell exhaustion and cancer immune escape (93). HMA and ICI combination is being investigated in trials.

ICI combination therapy with radiotherapy. Radiotherapy promotes tumour-specific antigen presentation. The abscopal effect is a systemic immune mediated regression of nonirradiated lesions distant from the primary irradiation site (94). Preclinical evidence supports combination of stereotactic body radiation therapy (SBRT) with ICIs (95). Radiotherapy sequencing and fractionation alters responses. Radiotherapy combination with anti-CTLA-4 only produced an abscopal effect with fractionation (96). Abscopal response is facilitated via altered antibody response to TAA, modified peripheral blood immune cells, and increased antigen responsiveness 
(97). Increased tumour-infiltrating lymphocytes were observed in non-irradiated lymph nodes of patients treated with ICI plus radiation (98).

\section{Threats to ICIs.}

Despite their clinical efficacy, ICIs' spectrum of use is narrow in haematological malignancies, whereas their role is more prominent in solid tumours. Even though ICIs are a cost-effective, off-the-shelf immunotherapy with universal utility across patients, their use in haematological malignancies will likely be overshadowed by the advent of more novel immunotherapeutic approaches, for example, Tcell-redirecting immunotherapies and adoptive cell therapies.

\section{Bispecific T-cell Engagers (BiTEs)}

Biological rationale for anti-cancer mechanism and development.

The concept of selectively targeting tumours via antibodies was proposed over a century ago by Paul Ehrlich (99). Monoclonal antibodies (mAbs) have constituted a weapon in the oncologists' anti-cancer armamentarium since 1997, commencing with the approval of rituximab, a chimeric anti-CD20 agent for low-grade B-cell lymphoma (100). Improvements in antibody engineering technology (101) have enabled scientists to develop bispecific T-cell-redirecting antibodies which bind TAAs, redirecting cytotoxic T-cells to tumours. Bispecific T-cell engagers (BiTEs), consisting of two different single-chain variable fragments (scFvs) derived from the antigen-binding domains of anti-CD3 and anti-TAA antibodies covalently bound via small linker peptides (102).

BiTEs are producible in large quantities through mammalian cell line culture and recombinant single-chain polypeptide secretion (103). Upon simultaneous binding of BiTEs to TAAs and CD3 TCR, a lytic immune synapse forms between T-cells and cancer cells (Figure 4) (104). Simultaneous high affinity binding is facilitated by small size $(\sim 55 \mathrm{kDa})$ and high flexibility of BiTEs due to lack of antibody constant $(\mathrm{Fc})$ regions, which also contributes to reduced half-life and decreased toxicity due to lack of Fc-receptor $(\mathrm{FcR})$ recycling and FcR-mediated effector functions, respectively (105). These characteristics are crucial for in vitro and in vivo efficacy. Tcell-mediated tumour cell killing was observed at very low concentrations (10-100 pg/ml) and low effector-cell to T-cell
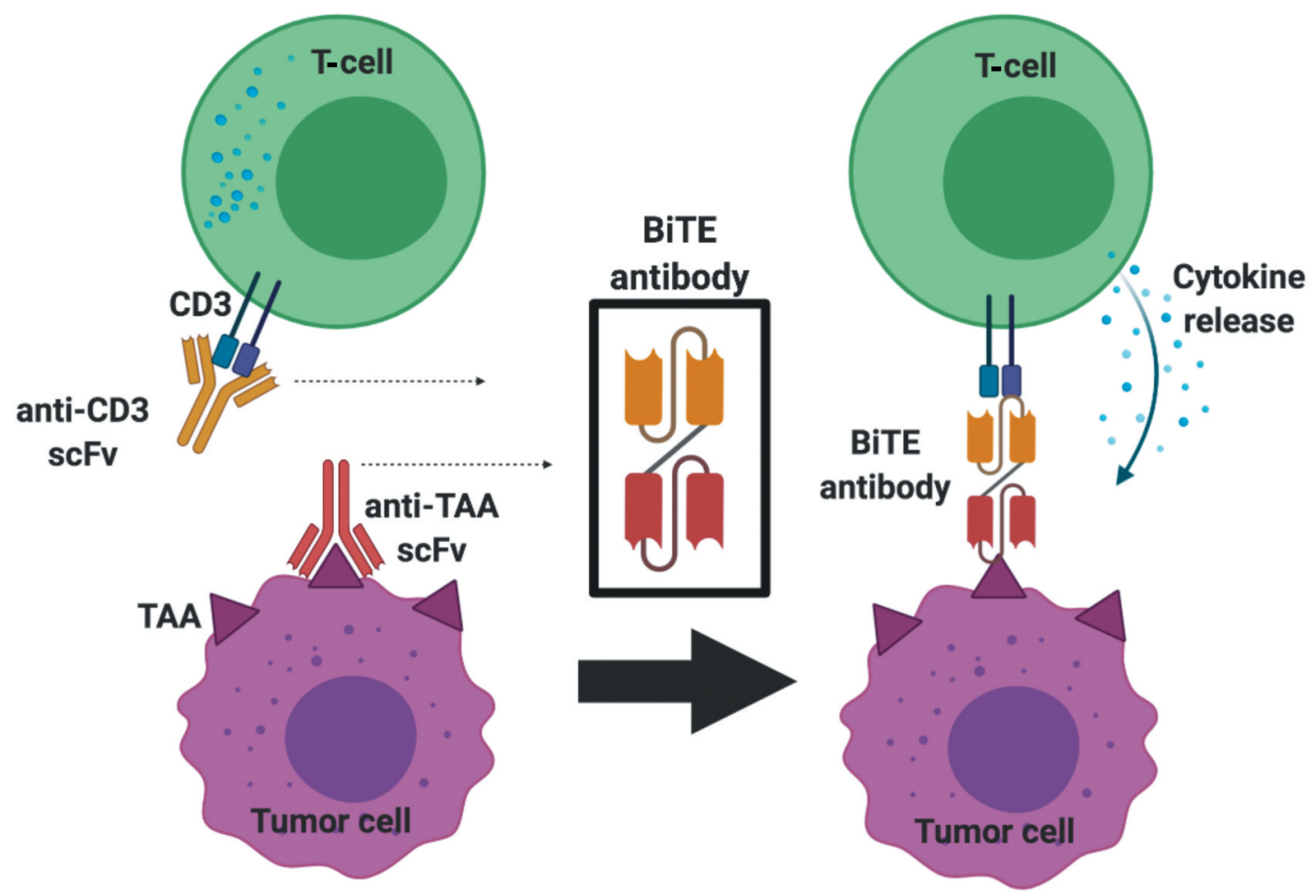

Figure 4. Schematic illustration of Bispecific T-cell Engager (BiTE) structure and mechanism of action. An anti-tumour-associated antigen (TAA) single-chain variable fragment ( $s c F v$ ) (shown in green) is linked via a small linker molecule to an anti-CD3 scFv (shown in pink). Binding of antiTAA to tumour cell surface antigens redirects T-cells to target the tumour cell via anti-CD3 binding causing the formation of a lytic immune synapse with cytokine release. Adapted with permission from Marayati et al. (104). 
ratios (<1:90), without immune co-stimulation (106-108). Hence, blinatumomab ultimately became the first approved BiTE and is still used in ALL subtypes. Several trials are investigating BiTEs in haematological and solid malignancies (109). Mosunetuzumab was recently pre-approved for $\mathrm{R} / \mathrm{R}$ follicular lymphoma (FL).

\section{Clinical translation.}

Blinatumomab (Blincyto ${ }^{\circledR}$ ). In 2014 blinatumomab, an antiCD19 and anti-CD3 agent, was approved for $\mathrm{Ph}$ chromosome $(\mathrm{Ph})$-negative (110), and subsequently $\mathrm{Ph}$ positive (111), B-cell precursor acute lymphoblastic leukaemia (BCP-ALL); nearly 60 years after the first report of human-synthesised bispecific antibodies (112, 113). Blinatumomab approval has been expanded to adults and children with R/R BCP-ALL, and adults and children with MRD-positive BCP-ALL in remission.

FDA approval was based on a phase II, open-label, singlearm, multicentre trial of $\mathrm{R} / \mathrm{R} \mathrm{Ph}^{-} \mathrm{BCP}$-ALL patients in which $33 \% \mathrm{CR}$ and 10\% $\mathrm{CRh}$ (complete remission with partial haematological recovery) was achieved, with 6.9-month median OS (114). A phase III randomised trial reported similar results with $44 \% \mathrm{CR} / \mathrm{CRh}$ rate and 7.7-month median OS. Blinatumomab was superior to chemotherapy (115). The openlabel, multicentre, single-arm study granting blinatumomab approval for $\mathrm{MRD}^{+} \mathrm{BCP}-\mathrm{ALL}$ evaluated patients experiencing first- or second-time $\mathrm{CR}$ with detectable MRD in a $>1$ in 1,000 bone marrow cells (116). MRD conversion to $<0.01 \%$ after one blinatumomab cycle was achieved in $85.2 \%$ and $72.0 \%$ of firstand second-CR patients, respectively, with 35.2-month and 12.3-months median haematologic relapse-free survival, respectively, indicating durable response. At 5 years, $50 \%$ remained in remission (117). A phase I/II trial was the first to demonstrate the safety and efficacy of single-agent blinatumomab in paediatric patients with $\mathrm{R} / \mathrm{R}$ BCP-ALL achieving complete minimal residual disease response (118).

Blinatumomab is generally well-tolerated. Toxicities reflect CD3-activation (109). Cytokine release syndrome (CRS) and neurotoxicity were rare but severe dose-limiting ARs issued Boxed Warnings in addition to pancreatitis, serious infection and sepsis $(114,115)$.

Mosunetuzumab (BTCT4465A). In July 2020, mosunetuzumab, an anti-CD20 and anti-CD3 agent, received pre-approval by the FDA, through breakthrough therapy designation, for the treatment of adults with $\mathrm{R} / \mathrm{R}$ follicular lymphoma (FL) after at least two prior systemic therapies. The phase $\mathrm{I} / \mathrm{Ib}$, multicentre, open-label, dose-escalation study evaluated the safety and pharmacokinetics of mosunetuzumab in 270 heavily pre-treated R/R NHL (119). ORR and CR was observed in indolent (63\% and 43\%) and aggressive lymphomas (37\% and 19\%) across doses. CRS and neurological ARs occurred in $29 \%$ and $44 \%$, respectively, but only three were grade 3 cases in each. Notably, patients previously receiving CAR-T-cell therapy $(\mathrm{n}=18)$ achieved $39 \%$ ORR (n=7) and 22\% CR (n=4) (120). Investigators observed a lymphocyte expansion, including residual CAR-T-cells, and CRs with and without CAR-T-cell expansions offering potential for mosunetuzumab salvage therapy after CAR-Tcells, though it could potentially be a bridging approach as well by stimulating T-cells.

\section{Strengths of BiTEs.}

Superior anti-tumour efficacy. Preclinically, BiTE efficacy is superior to mAbs and other bispecific antibodies $(106,121)$. Higher binding specificity due to two antigens and effector immune cell mediated redirection to tumour cells enhance cytotoxicity. Targeting two pathways improves efficacy and resistance (122). Indeed, in a phase I/Ib study mosunetuzumab demonstrated clinical activity and durable response in R/R Bcell NHL patients who were considered refractory to antiCD20 therapy and in patients who had relapsed following CD19-directed CAR-T therapy, while the safety profile also appeared favourable compared to standard anti-lymphoma therapies including T-cell directed agents (123).

Lack of MHC and HLA restriction. Lack of major histocompatibility complex (MHC)- and human leukocyte antigen (HLA)-restriction in BiTEs allows for universal offthe-shelf use unlike CAR-T-cells. MHC-independent cancer elimination prevents resistance via MHC-molecule downregulation, loss of MHC-I associated $\beta 2$-microglobulin or intracellular peptide transporters (124).

\section{Weaknesses of BiTEs.}

Rare but severe toxicities. CRS, observed in $\mathrm{mAb}$, bispecific antibody, and CAR-T-cell treatments, is a direct result of lymphoid- and/or myeloid-cell activation which stimulates cytokine production, including interleukin IL-6 and interferon$\gamma($ IFN- $\gamma)(125)$. While mild CRS produces fever, severe cases can mimic macrophage activation syndrome or hemophagocytic lymphohistiocytosis (126). CRS has been observed with blinatumomab (127) and occurs within days from the first cycle but not subsequent infusions (128). CRS incidence is positively correlated with dose and disease burden (114, 128-130). CRS also correlates with better response, though severity is not response-associated (131). Prophylactic dexamethasone and stepwise dosing decreased CRS incidence (114, 132). Tocilizumab, an anti-IL-6 receptor mAb for CD19-CAR-T-cell CRS (125, 133), can treat blinatumomab-associated CRS (134).

Blinatumomab-treatment neurotoxicity (52\%) encompasses a spectrum of presentations (109). Most are mild such as grade 2 tremor (17\%), while seizures (2\%) or encephalopathy $(5 \%)$ are rare. BiTE neurotoxicity has been attributed to extravasation of adhesive T-cells to the perivascular space in the central nervous system, stimulating endothelial activation which attracts leukocytes, including monocytes, inducing 
neuroinflammation and neurotoxicity (135). Neurological ARs are reversible on treatment discontinuation and dexamethasone therapy. Similar to CRS, prophylactic dexamethasone and stepwise dosing regimens are advised.

Relapse and resistance. Increased tumour mutational burden negatively correlates to blinatumomab response due to mutation-associated primary resistance (136). Lineage switch to acute myeloid leukaemia (AML) by rearrangement of the myeloid/lymphoid or mixed lineage leukaemia (MLL) lysine (K)-specific methyltransferase 2A (KMT2A) gene expressed on B-cell ALL can cause relapse or resistance (137). TAA target downregulation is a significant cause of blinatumomab resistance (138). Decreased CD19 expression on leukemic blasts prior to, and after blinatumomab therapy confers primary and secondary resistance, respectively (139). CD19 gene mutations and alternate splicing of CD19 mRNA produce truncated receptor variants conferring resistance (140).

\section{Opportunities for BiTEs.}

New antigen targets. Over 100 bispecific antibody formats are known $(101,141,142)$, a quarter of which are being commercialised by pharmaceutical companies for therapeutic development (143). CD20, BCMA, CD138, CD33, CD123, CLL1, WT1, CD13 TAA-directed domains are being investigated in haematological cancers (109).

New antibody formats. Dual-affinity re-targeting (DART) offers competing diabody format with additional stability through a Cterminal disulphide bridge (144). In vitro CD19xCD3 DARTs outperform BiTEs in cytotoxicity assays (145). DARTs demonstrate higher CD3-association, lower CD19 dissociation, and more efficient $\mathrm{T}$ - and $\mathrm{B}$-cell cross-linking. CD19xCD3 DART, duvortuxizumab, demonstrated response in phase I dose escalation. However, high neurotoxicity rates terminated licensing due to high competition against B-cell malignancy therapies. CD32BxCD16 and CD32BxCD79B DARTs provide an alternative T-cell activation mechanism, highlighting bispecific antibody adaptability.

\section{Threats to BiTEs.}

Interest in BiTEs has decreased given unsuccessful attempts to translate agents despite numerous trials. Other designs, such as DARTs, have gained interest. Adoptive cell therapies threaten the sustainability of BiTEs. CD19-CAR-T-cell therapy approval for ALL is altering blinatumomab prescribing. Novel adoptive cell therapies are superior and offer durable remission (109).

\section{Discussion}

ICIs and BiTEs are exceptional treatments for haematological malignancies. Yet, biotechnological advancements underlying immunotherapeutic development are costly. Thus, close consideration of the strengths, weaknesses, opportunities and threats of each immunotherapeutic modality is essential to direct future research (Table II). Both ICIs and BiTEs are costeffective "off-the-shelf" drugs. ICIs generate durable response in heavily pre-treated and disease refractory patients. However, limited response across patients and diseases, primary and acquired resistance, and rare but severe toxicities, have set ICIs behind novel ATC therapies such as CARs. Nevertheless, lower costs and longer history of approval compared to BiTEs and novel ATC therapies lends to their continued interest. BiTEs represent powerful immunotherapies with superior anti-tumour efficacy to other antibody contracts. However, costly initial synthesis and competitive licensing have restricted their use, though newer constructs may change this.

Table II. Summary of strengths, weaknesses, opportunities and threats associated with immune checkpoint inhibitors and bispecific T-cell engagers.

\begin{tabular}{lll}
\hline & Immune checkpoint inhibitors & Bispecific T-cell engagers \\
\hline Strengths & $\begin{array}{l}\text { Responses in heavily pre-treated/resistant disease } \\
\text { Durable response } \\
\text { Relatively well-tolerated } \\
\text { Lack of MHC and HLA restriction }\end{array}$ & $\begin{array}{l}\text { Superior anti-tumour efficacy } \\
\text { Lack of MHC and HLA restriction }\end{array}$ \\
Weaknesses & $\begin{array}{l}\text { Rare but severe toxicities } \\
\text { Slow response, pseudoprogression, and hyperprogression }\end{array}$ & Rare but severe toxicities \\
& Limited response and associated resistance & Relapse and resistance \\
Opportunities & $\begin{array}{l}\text { New targets } \\
\text { Resistance mechanisms and response prediction } \\
\text { Combination therapy }\end{array}$ & $\begin{array}{l}\text { New antibody formats } \\
\text { New antigen targets }\end{array}$ \\
Threats & $\begin{array}{l}\text { Novel T-cell-redirecting immunotherapies }(e . g ., \text { BiTEs) } \\
\text { Novel adoptive cell therapies }(e . g ., \text { CAR-T-cells })\end{array}$ & Novel adoptive cell therapy agents $(e . g .$, CAR-T-cells) \\
\hline
\end{tabular}




\section{Conclusion}

With new molecular targets being discovered, more progress is to be expected in T-cell-based cancer immunotherapy. The diverse repertoire of molecular targets offers exceptional potential for combination treatments. Clinically, combination immunotherapy is still at its relative infancy with further research necessary to determine how to optimise and translate treatment regimens into routine clinical practice. The potential to combine immunotherapies with chemotherapy, radiotherapy, and targeted molecular therapies is significant and requires systematic investigation.

\section{Conflicts of Interest}

The Authors declare that they have no competing interests.

\section{Authors' Contributions}

K.S.R. has contributed to reviewing the literature, drafting and revising the article, figure illustrations, and final approval of the version to be published. C.R.T.H. has contributed to revising the article and final approval of the version to be published. M.S. has contributed to revising the article and final approval of the version to be published. J.K.F. has contributed to the conceptualization of the work, revising the article, supervising the work, and final approval of the version to be published.

\section{Acknowledgements}

Figures created with BioRender.com. Figure 4 adapted with permission from Marayati R, Quinn $\mathrm{CH}$ and Beierle EA: Immunotherapy in pediatric solid tumors - a systematic review. Cancers 11(12): 2022, 2019, published under the Creative Commons Attribution License which permits unrestricted use, distribution, and reproduction in any medium, provided the original work is properly cited.

\section{References}

1 Waldman AD, Fritz JM and Lenardo MJ: A guide to cancer immunotherapy: from $\mathrm{T}$ cell basic science to clinical practice. Nat Rev Immunol 20(11): 651-668, 2020. PMID: 32433532. DOI: $10.1038 / \mathrm{s} 41577-020-0306-5$

2 Jenkins M and Schwartz R: Antigen presentation by chemically modified splenocytes induces antigen-specific $\mathrm{T}$ cell unresponsiveness in vitro and in vivo. Journal of Experimental Medicine 165(2): 302-319, 2020. DOI: 10.1084/jem.165.2.302

3 Bretscher $\mathrm{P}$ and Cohn M: A theory of self-nonself discrimination. Science 169(3950): 1042-1049, 1970. PMID: 4194660. DOI: $10.1126 /$ science.169.3950.1042

4 Cunningham AJ and Lafferty KJ: Letter: cellular proliferation can be an unreliable index of immune competence. J Immunol Baltim Md 1950 112(1): 436-437, 1974. PMID: 4855833.

5 Bretscher PA: A two-step, two-signal model for the primary activation of precursor helper T cells. Proc Natl Acad Sci USA 96(1): 185-190, 1999. PMID: 9874793. DOI: 10.1073/pnas. 96.1 .185
6 Holtzman MJ, Green JM, Jayaraman S and Arch RH: Regulation of T cell apoptosis. Apoptosis 5(5): 459-471, 2000. DOI: $10.1023 / \mathrm{A}: 1009657321461$.

7 Darvin P, Toor SM, Sasidharan Nair V and Elkord E: Immune checkpoint inhibitors: recent progress and potential biomarkers. Exp Mol Med 50(12): 1-11, 2018. DOI: 10.1038/s12276-018-0191-1

8 Smyth MJ and Teng MW: 2018 Nobel Prize in physiology or medicine. Clin Transl Immunol 7(10):e1041, 2018. PMID: 30386598. DOI: $10.1002 / \mathrm{cti} 2.1041$

9 Sharpe AH and Freeman GJ: The B7-CD28 superfamily. Nat Rev Immunol 2(2): 116-126, 2002. DOI: 10.1038/nri727

10 Linsley PS, Bradshaw J, Greene J, Peach R, Bennett KL and Mittler RS: Intracellular trafficking of CTLA-4 and focal localization towards sites of TCR engagement. Immunity 4(6): 535-543, 1996. DOI: 10.1016/S1074-7613(00)80480-X

11 Gross JA, Callas E and Allison JP: Identification and distribution of the costimulatory receptor $\mathrm{CD} 28$ in the mouse. J Immunol 149(2): 380-388, 1992. PMID: 1320641

12 Coyle AJ and Gutierrez-Ramos JC: The expanding B7 superfamily: increasing complexity in costimulatory signals regulating T cell function. Nat Immunol 2(3): 203-209, 2001. PMID: 11224518 . DOI: $10.1038 / 85251$

13 Aruffo A and Seed B: Molecular cloning of a CD28 cDNA by a high-efficiency COS cell expression system. Proc Natl Acad Sci USA 84(23): 8573-8577, 1987. PMID: 2825196. DOI: 10.1073/pnas.84.23.8573

14 Sansom DM and Hall ND: B7/BB1, the ligand for CD28, is expressed on repeatedly activated human T cells in vitro. Eur J Immunol 23(1): 295-298, 1993. PMID: 7678229. DOI: 10.1002/eji.1830230148

15 Yokochi T, Holly RD and Clark EA: B lymphoblast antigen (BB-1) expressed on Epstein-Barr virus-activated B cell blasts, B lymphoblastoid cell lines, and Burkitt's lymphomas. J Immunol 128(2): 823-827, 1982. PMID: 6274961

16 Freeman GJ, Gray GS, Gimmi CD, Lombard DB, Zhou LJ, White M, Fingeroth JD, Gribben JG and Nadler LM: Structure, expression, and $\mathrm{T}$ cell costimulatory activity of the murine homologue of the human B lymphocyte activation antigen B7. J Exp Med 174(3): 625-631, 1991. PMID: 1714935. DOI: 10.1084/jem.174.3.625

17 Freedman AS, Freeman G, Horowitz JC, Daley J and Nadler LM: B7, a B-cell-restricted antigen that identifies preactivated B cells. J Immunol 139(10): 3260-3267, 1987. PMID: 3500211

18 Azuma M, Ito D, Yagita H, Okumura K, Phillips JH, Lanier LL and Somoza C: B70 antigen is a second ligand for CTLA-4 and CD28. Nature 366(6450): 76-79, 1993. PMID: 7694153. DOI: $10.1038 / 366076 \mathrm{a} 0$

19 Freeman GJ, Borriello F, Hodes RJ, Reiser H, Gribben JG, Ng JW, Kim J, Goldberg JM, Hathcock K and Laszlo G: Murine B72, an alternative CTLA4 counter-receptor that costimulates T cell proliferation and interleukin 2 production. J Exp Med 178(6): 2185-2192, 1993. PMID: 7504059. DOI: 10.1084/jem.178.6.2185

20 Freeman GJ, Gribben JG, Boussiotis VA, Ng JW, Restivo VA Jr, Lombard LA, Gray GS and Nadler LM: Cloning of B7-2: a CTLA-4 counter-receptor that costimulates human $\mathrm{T}$ cell proliferation. Science 262(5135): 909-911, 1993. PMID: 7694363. DOI: $10.1126 /$ science.7694363

21 Peach R, Bajorath J, Brady W, Leytze G, Greene J, Naemura J and Linsley P: Complementarity determining region 1 (CDR1)and CDR3-analogous regions in CTLA-4 and CD28 determine 
the binding to B7-1. Journal of Experimental Medicine 180(6): 2049-2058, 2020. DOI: 10.1084/jem.180.6.2049

22 Linsley P, Greene J, Tan P, Bradshaw J, Ledbetter J, Anasetti C and Damle N: Coexpression and functional cooperation of CTLA-4 and CD28 on activated T lymphocytes. Journal of Experimental Medicine 176(6): 1595-1604, 2020. DOI: 10.1084/jem.176.6.1595

23 Linsley PS, Greene JL, Brady W, Bajorath J, Ledbetter JA and Peach R: Human B7-1 (CD80) and B7-2 (CD86) bind with similar avidities but distinct kinetics to CD28 and CTLA-4 receptors. Immunity 1(9): 793-801, 1994. PMID: 7534620. DOI: 10.1016/s1074-7613(94)80021-9

24 Stamper CC, Zhang Y, Tobin JF, Erbe DV, Ikemizu S, Davis SJ, Stahl ML, Seehra J, Somers WS and Mosyak L: Crystal structure of the B7-1/CTLA-4 complex that inhibits human immune responses. Nature 410(6828): 608-611, 2001. PMID: 11279502. DOI: $10.1038 / 35069118$

25 Carreno BM, Bennett F, Chau TA, Ling V, Luxenberg D, Jussif J, Baroja ML and Madrenas J: CTLA-4 (CD152) can inhibit T cell activation by two different mechanisms depending on its level of cell surface expression. J Immunol 165(3): 1352-1356, 2000. PMID: 10903737. DOI: 10.4049/jimmunol.165.3.1352

26 Brunet JF, Denizot F, Luciani MF, Roux-Dosseto M, Suzan M, Mattei MG and Golstein P: A new member of the immunoglobulin superfamily - CTLA-4. Nature 328(6127): 267-270, 1987. PMID: 3496540. DOI: 10.1038/328267a0

27 Linsley PS, Brady W, Urnes M, Grosmaire LS, Damle NK and Ledbetter JA: CTLA-4 is a second receptor for the B cell activation antigen B7. J Exp Med 174(3): 561-569, 1991. PMID: 1714933. DOI: 10.1084/jem.174.3.561

28 Fraser JH, Rincón M, McCoy KD and Le Gros G: CTLA4 ligation attenuates AP-1, NFAT and NF-kappaB activity in activated T cells. Eur J Immunol 29(3): 838-844, 1999. PMID: 10092086. DOI: 10.1002/(SICI) 1521-4141(199903)29:03<838::AID-IMMU 838>3.0.CO;2-P

29 Olsson C, Riesbeck K, Dohlsten M and Michaëlsson E: CTLA-4 ligation suppresses CD28-induced NF-kappaB and AP-1 activity in mouse T cell blasts. J Biol Chem 274(20): 14400-14405, 1999. PMID: 10318864. DOI: 10.1074/jbc.274.20.14400

30 Brunner MC, Chambers CA, Chan FK, Hanke J, Winoto A and Allison JP: CTLA-4-Mediated inhibition of early events of T cell proliferation. J Immunol 162(10): 5813-5820, 1999. PMID: 10229815

31 Calvo CR, Amsen D and Kruisbeek AM: Cytotoxic T lymphocyte antigen 4 (CTLA-4) interferes with extracellular signal-regulated kinase (ERK) and Jun NH2-terminal kinase (JNK) activation, but does not affect phosphorylation of T cell receptor zeta and ZAP70. J Exp Med 186(10): 1645-1653, 1997. PMID: 9362525. DOI: $10.1084 /$ jem.186.10.1645

32 Park JA and Cheung NV: Limitations and opportunities for immune checkpoint inhibitors in pediatric malignancies. Cancer Treat Rev 58: 22-33, 2017. PMID: 28622628. DOI: 10.1016/j.ctrv.2017.05.006

33 Grosso JF and Jure-Kunkel MN: CTLA-4 blockade in tumor models: an overview of preclinical and translational research. Cancer Immun 13: 5, 2013. PMID: 23390376.

34 Yang YF, Zou JP, Mu J, Wijesuriya R, Ono S, Walunas T, Bluestone J, Fujiwara H and Hamaoka T: Enhanced induction of antitumor T-cell responses by cytotoxic $\mathrm{T}$ lymphocyteassociated molecule-4 blockade: the effect is manifested only at the restricted tumor-bearing stages. Cancer Res 57(18): 40364041, 1997. PMID: 9307290.

35 Ishida $\mathrm{Y}$, Agata $\mathrm{Y}$, Shibahara $\mathrm{K}$ and Honjo T: Induced expression of PD-1, a novel member of the immunoglobulin gene superfamily, upon programmed cell death. EMBO J 11(11): 3887-3895, 1992. PMID: 1396582

36 Freeman G, Long A, Iwai Y, Bourque K, Chernova T, Nishimura H, Fitz L, Malenkovich N, Okazaki T, Byrne M, Horton H, Fouser L, Carter L, Ling V, Bowman M, Carreno B, Collins M, Wood C and Honjo T: Engagement of the Pd-1 immunoinhibitory receptor by a novel B7 family member leads to negative regulation of lymphocyte activation. Journal of Experimental Medicine 192(7): 1027-1034, 2020. DOI: 10.1084/jem.192.7.1027

37 Dong H, Zhu G, Tamada K and Chen L: B7-H1, a third member of the B7 family, co-stimulates T-cell proliferation and interleukin-10 secretion. Nature Medicine 5(12): 1365-1369, 2018. DOI: $10.1038 / 70932$

38 Latchman Y, Wood C, Chernova T, Chaudhary D, Borde M, Chernova I, Iwai Y, Long A, Brown J, Nunes R, Greenfield E, Bourque K, Boussiotis V, Carter L, Carreno B, Malenkovich N, Nishimura H, Okazaki T, Honjo T, Sharpe A and Freeman G: PD-L2 is a second ligand for PD-1 and inhibits T cell activation. Nature Immunology 2(3): 261-268, 2019. DOI: 10.1038/85330

39 Tseng S, Otsuji M, Gorski K, Huang X, Slansky J, Pai S, Shalabi A, Shin T, Pardoll D and Tsuchiya H: B7-Dc, a new dendritic cell molecule with potent costimulatory properties for $\mathrm{T}$ cells. Journal of Experimental Medicine 193(7): 839-846, 2020. DOI: $10.1084 /$ jem.193.7.839

40 Fife BT and Bluestone JA: Control of peripheral T-cell tolerance and autoimmunity via the CTLA-4 and PD-1 pathways. Immunol Rev 224: 166-182, 2008. PMID: 18759926. DOI: $10.1111 / \mathrm{j} .1600-065 X .2008 .00662 . \mathrm{x}$

41 Keir ME, Butte MJ, Freeman GJ and Sharpe AH: PD-1 and its ligands in tolerance and immunity. Annu Rev Immunol 26: 677704, 2008. PMID: 18173375. DOI: 10.1146/annurev.immunol. 26.021607.090331

42 Hui E, Cheung J, Zhu J, Su X, Taylor MJ, Wallweber HA, Sasmal DK, Huang J, Kim JM, Mellman I and Vale RD: T cell costimulatory receptor $\mathrm{CD} 28$ is a primary target for PD-1mediated inhibition. Science 355(6332): 1428-1433, 2017. PMID: 28280247. DOI: 10.1126/science.aaf1292

43 Kim ES, Kim JE, Patel MA, Mangraviti A, Ruzevick J and Lim M: Immune Checkpoint Modulators: An emerging antiglioma armamentarium. J Immunol Res 2016(7): e4683607, 2016. PMID: 26881264. DOI: $10.1155 / 2016 / 4683607$

44 Chen L and Flies DB: Molecular mechanisms of T cell costimulation and co-inhibition. Nat Rev Immunol 13(4): 227242, 2013. PMID: 23470321. DOI: $10.1038 /$ nri3405

45 Boussiotis VA: Molecular and Biochemical Aspects of the PD1 Checkpoint Pathway. N Engl J Med 375(18): 1767-1778, 2016. PMID: 27806234. DOI: 10.1056/NEJMra1514296

46 Iwai Y, Terawaki S and Honjo T: PD-1 blockade inhibits hematogenous spread of poorly immunogenic tumor cells by enhanced recruitment of effector T cells. Int Immunol 17(2): 133144, 2005. PMID: 15611321. DOI: 10.1093/intimm/dxh194

47 Thompson RH, Dong H, Lohse CM, Leibovich BC, Blute ML, Cheville JC and Kwon ED: PD-1 is expressed by tumorinfiltrating immune cells and is associated with poor outcome for patients with renal cell carcinoma. Clin Cancer Res 13(6): 
1757-1761, 2007. PMID: 17363529. DOI: 10.1158/10780432.CCR-06-2599

48 Thompson RH, Kuntz SM, Leibovich BC, Dong H, Lohse CM, Webster WS, Sengupta S, Frank I, Parker AS, Zincke H, Blute ML, Sebo TJ, Cheville JC and Kwon ED: Tumor B7-H1 is associated with poor prognosis in renal cell carcinoma patients with long-term follow-up. Cancer Res 66(7): 3381-3385, 2006. PMID: 16585157. DOI: 10.1158/0008-5472.CAN-05-4303

49 Garon EB, Rizvi NA, Hui R, Leighl N, Balmanoukian AS, Eder JP, Patnaik A, Aggarwal C, Gubens M, Horn L, Carcereny E, Ahn MJ, Felip E, Lee JS, Hellmann MD, Hamid O, Goldman JW, Soria JC, Dolled-Filhart M, Rutledge RZ, Zhang J, Lunceford JK, Rangwala R, Lubiniecki GM, Roach C, Emancipator K, Gandhi L and KEYNOTE-001 Investigators.: Pembrolizumab for the treatment of non-small-cell lung cancer. N Engl J Med 372(21): 2018-2028, 2015. PMID: 25891174. DOI: $10.1056 /$ NEJMoa1501824

50 Vaddepally RK, Kharel P, Pandey R, Garje R and Chandra AB: Review of Indications of FDA-Approved Immune Checkpoint Inhibitors per NCCN Guidelines with the Level of Evidence. Cancers (Basel) 12(3), 2020. PMID: 32245016. DOI: $10.3390 /$ cancers 12030738

51 Kasamon YL, de Claro RA, Wang Y, Shen YL, Farrell AT and Pazdur R: FDA approval Summary: nivolumab for the treatment of relapsed or progressive classical hodgkin lymphoma. The Oncologist 22(5): 585-591, 2017. PMID: 28438889. DOI: 10.1634/theoncologist.2017-0004

52 Younes A, Santoro A, Shipp M, Zinzani PL, Timmerman JM, Ansell S, Armand P, Fanale M, Ratanatharathorn V, Kuruvilla J, Cohen JB, Collins G, Savage KJ, Trneny M, Kato K, Farsaci B, Parker SM, Rodig S, Roemer MGM, Ligon AH and Engert A: Nivolumab for classical Hodgkin's lymphoma after failure of both autologous stem-cell transplantation and brentuximab vedotin: a multicentre, multicohort, single-arm phase 2 trial. Lancet Oncol 17(9): 1283-1294, 2016. PMID: 27451390. DOI: 10.1016/S1470-2045(16)30167-X

53 Ansell SM, Lesokhin AM, Borrello I, Halwani A, Scott EC, Gutierrez M, Schuster SJ, Millenson MM, Cattry D, Freeman GJ, Rodig SJ, Chapuy B, Ligon AH, Zhu L, Grosso JF, Kim SY, Timmerman JM, Shipp MA and Armand P: PD-1 blockade with nivolumab in relapsed or refractory hodgkin's lymphoma. N Engl J Med 372(4): 311-319, 2015. PMID: 25482239. DOI: 10.1056/NEJMoa1411087

54 Pembrolizumab Approved for Hodgkin Lymphoma. Cancer Discov 7(5): OF1, 2017. PMID: 28363910. DOI: 10.1158/21598290.CD-NB2017-044

55 Chen R, Zinzani PL, Fanale MA, Armand P, Johnson NA, Brice P, Radford J, Ribrag V, Molin D, Vassilakopoulos TP, Tomita A, Tresckow B von, Shipp MA, Zhang Y, Ricart AD, Balakumaran A, Moskowitz CH: Phase II study of the efficacy and safety of pembrolizumab for relapsed/refractory classic hodgkin lymphoma. J Clin Oncol 35(19):2125-2132, 2017. DOI: $10.1200 / J C O .2016 .72 .1316$

56 Armand P, Rodig SJ, Melnichenko V, Thieblemont C, Bouabdallah K, Tumyan G, Özcan M, Portino S, Fogliatto L, Caballero D, Walewski J, Gulbas Z, Ribrag V, Christian BA, Perini GF, Salles GA, Svoboda J, Zain JM, Patel SS, Chen PH, Ligon AH, Ouyang J, Neuberg DS, Redd RA, Chatterjee A, Orlowski RJ, Balakumaran A, Shipp MA and Zinzani PL: Pembrolizumab in patients with relapsed or refractory primary mediastinal large B-cell lymphoma (PMBCL): data from the KEYNOTE -013 and KEYNOTE-170 studies. Blood 132(Suppl 1): 228, 2018. DOI: 10.1182/blood-2018-99-110220

57 Ok CY and Young KH: Checkpoint inhibitors in hematological malignancies. J Hematol Oncol 10(1): 103, 2017. DOI: 10.1186/s13045-017-0474-3

58 Marjańska A, Drogosiewicz M, Dembowska-Bagińska B, Pawińska-Wąsikowska K, Balwierz W, Bobeff K, Młynarski W, Mizia-Malarz A, Raciborska A, Wysocki M and Styczyński J: Nivolumab for the treatment of advanced pediatric malignancies. Anticancer Res 40(12): 7095-7100, 2020. PMID: 33288608. DOI: 10.21873/anticanres. 14738

59 Ferris RL, Blumenschein G, Fayette J, Guigay J, Colevas AD, Licitra L, Harrington K, Kasper S, Vokes EE, Even C, Worden F, Saba NF, Iglesias Docampo LC, Haddad R, Rordorf T, Kiyota N, Tahara M, Monga M, Lynch M, Geese WJ, Kopit J, Shaw JW and Gillison ML: Nivolumab for recurrent squamous-cell carcinoma of the head and neck. N Engl J Med 375(19): 18561867, 2016. PMID: 27718784. DOI: 10.1056/NEJMoa1602252

60 Fares CM, Van Allen EM, Drake CG, Allison JP and HuLieskovan S: Mechanisms of resistance to immune checkpoint blockade: why does checkpoint inhibitor immunotherapy not work for all patients? Am Soc Clin Oncol Educ Book 39: $147-$ 164, 2019. DOI: 10.1200/EDBK_240837

61 Schoenfeld A and Hellmann M: Acquired resistance to immune checkpoint inhibitors. Cancer Cell 37(4): 443-455, 2021. DOI: 10.1016/j.ccell.2020.03.017

62 Schadendorf D, Hodi FS, Robert C, Weber JS, Margolin K, Hamid O, Patt D, Chen TT, Berman DM and Wolchok JD: Pooled analysis of long-term survival data from phase ii and phase III trials of ipilimumab in unresectable or metastatic melanoma. J Clin Oncol 33(17): 1889-1894, 2015. PMID: 25667295. DOI: $10.1200 / J C O .2014 .56 .2736$

63 Maio M, Grob JJ, Aamdal S, Bondarenko I, Robert C, Thomas L, Garbe C, Chiarion-Sileni V, Testori A, Chen TT, Tschaika M and Wolchok JD: Five-year survival rates for treatment-naive patients with advanced melanoma who received ipilimumab plus dacarbazine in a phase III trial. J Clin Oncol 33(10): 1191-1196, 2015. PMID: 25713437. DOI: 10.1200/JCO.2014.56.6018

64 Lipson EJ, Sharfman WH, Drake CG, Wollner I, Taube JM, Anders RA, Xu H, Yao S, Pons A, Chen L, Pardoll DM, Brahmer JR and Topalian SL: Durable cancer regression offtreatment and effective reinduction therapy with an anti-PD-1 antibody. Clin Cancer Res 19(2): 462-468, 2013. PMID: 23169436. DOI: 10.1158/1078-0432.CCR-12-2625

65 Wang DY, Johnson DB and Davis EJ: Toxicities associated With PD-1/PD-L1 blockade. Cancer J 24(1): 36-40, 2018. PMID: 29360726. DOI: 10.1097/PPO.0000000000000296

66 Borcoman E, Nandikolla A, Long G, Goel S and Le Tourneau C: Patterns of response and progression to immunotherapy. American Society of Clinical Oncology Educational Book (38): 169-178, 2021. DOI: 10.1200/EDBK_200643

67 Denis M, Duruisseaux M, Brevet M and Dumontet C: How can immune checkpoint inhibitors cause hyperprogression in solid tumors? Front Immunol 11: 492, 2020. PMID: 32265935. DOI: 10.3389/fimmu.2020.00492

68 Veldman J, Visser L, Berg A and Diepstra A: Primary and acquired resistance mechanisms to immune checkpoint inhibition in Hodgkin lymphoma. Cancer Treatment Reviews 82: 101931, 2020. DOI: 10.1016/j.ctrv.2019.101931 
69 Zhu Y, Yao S and Chen L: Cell surface signaling molecules in the control of immune responses: a tide model. Immunity 34(4): 466478, 2011. PMID: 21511182. DOI: 10.1016/j.immuni.2011.04.008

70 Gide TN, Wilmott JS, Scolyer RA and Long GV: Primary and acquired resistance to immune checkpoint inhibitors in metastatic melanoma. Clin Cancer Res 24(6): 1260-1270, 2018. PMID: 29127120. DOI: 10.1158/1078-0432.CCR-172267

71 Ngiow SF, von Scheidt B, Akiba H, Yagita H, Teng MW and Smyth MJ: Anti-TIM3 antibody promotes $\mathrm{T}$ cell IFN- $\gamma$ mediated antitumor immunity and suppresses established tumors. Cancer Res 71(10): 3540-3551, 2011. PMID: 21430066. DOI: 10.1158/0008-5472.CAN-11-0096

72 Woo SR, Turnis ME, Goldberg MV, Bankoti J, Selby M, Nirschl CJ, Bettini ML, Gravano DM, Vogel P, Liu CL, Tangsombatvisit S, Grosso JF, Netto G, Smeltzer MP, Chaux A, Utz PJ, Workman CJ, Pardoll DM, Korman AJ, Drake CG and Vignali DA: Immune inhibitory molecules LAG-3 and PD-1 synergistically regulate T-cell function to promote tumoral immune escape. Cancer Res 72(4): 917-927, 2012. PMID: 22186141. DOI: 10.1158/0008-5472.CAN-11-1620

73 Komiya T and Huang CH: Updates in the clinical development of epacadostat and other indoleamine 2,3-dioxygenase 1 inhibitors (IDO1) for human cancers. Front Oncol 8: 423, 2018. PMID: 30338242. DOI: 10.3389/fonc 2018.00423

74 Rao SV, Moran AE and Graff JN: Predictors of response and resistance to checkpoint inhibitors in solid tumors. Ann Transl Med 5(23): 468, 2017. PMID: 29285501. DOI: 10.21037/atm.2017.09.35

75 Nakamura Y: Biomarkers for immune checkpoint inhibitormediated tumor response and adverse events. Frontiers in Medicine 6, 2019. DOI: 10.3389/fmed.2019.00119

$76 \mathrm{Wu} \mathrm{Y,} \mathrm{Xu} \mathrm{J,} \mathrm{Du} \mathrm{C,} \mathrm{Wu} \mathrm{Y,} \mathrm{Xia} \mathrm{D,} \mathrm{Lv} \mathrm{W} \mathrm{and} \mathrm{Hu} \mathrm{J:} \mathrm{The}$ predictive value of tumor mutation burden on efficacy of immune checkpoint inhibitors in cancers: A systematic review and meta-analysis. Front Oncol 9: 1161, 2019. PMID: 31750249. DOI: $10.3389 /$ fonc. 2019.01161

77 Lee C, Man J, Lord S, Links M, Gebski V, Mok T and Yang J: Checkpoint inhibitors in metastatic EGFR- mutated non-small cell lung cancer - A meta-analysis. Journal of Thoracic Oncology 12(2): 403-407, 2019. DOI: $10.1016 /$ j.jtho.2016.10.007

78 Torralvo J, Friedlaender A, Achard V and Addeo A: The activity of immune checkpoint inhibition in KRAS mutated non-small cell lung cancer: A single centre experience. Cancer Genomics Proteomics 16(6): 577-582, 2019. PMID: 31659111. DOI: $10.21873 / \operatorname{cgp} .20160$

79 Han SY, Jahagirdar BN and Dudek AZ: Two malignancies with differential responses to immune checkpoint inhibitors: A case report. Anticancer Res 40(5): 2821-2826, 2020. PMID: 32366429. DOI: 10.21873/anticanres.14255

80 Furukawa K, Kawasaki G, Yoshida $\mathrm{T}$ and Umeda M: Clinicopathological and prognostic analysis of PD-L1 and PDL2 expression in surgically resected primary tongue squamous cell carcinoma. Anticancer Res 41(1): 101-111, 2021. PMID: 33419803. DOI: 10.21873/anticanres.14755

81 Ansell S, Gutierrez M, Shipp M, Gladstone D, Moskowitz A, Borello I, Popa-mckiver M, Farsaci B, Zhu L, Lesokhin A and Armand P: A Phase 1 study of nivolumab in combination with ipilimumab for relapsed or refractory hematologic malignancies (CheckMate 039). Blood 128(22): 183-183, 2019. DOI: 10.1182/blood.V128.22.183.183
82 Wolchok JD, Kluger H, Callahan MK, Postow MA, Rizvi NA, Lesokhin AM, Segal NH, Ariyan CE, Gordon RA, Reed K, Burke MM, Caldwell A, Kronenberg SA, Agunwamba BU, Zhang X, Lowy I, Inzunza HD, Feely W, Horak CE, Hong Q, Korman AJ, Wigginton JM, Gupta A and Sznol M: Nivolumab plus ipilimumab in advanced melanoma. N Engl J Med 369(2): 122133, 2013. PMID: 23724867. DOI: 10.1056/NEJMoa1302369

83 Krupka C, Kufer P, Kischel R, Zugmaier G, Lichtenegger FS, Köhnke T, Vick B, Jeremias I, Metzeler KH, Altmann T, Schneider S, Fiegl M, Spiekermann K, Bauerle PA, Hiddemann W, Riethmüller G and Subklewe M: Blockade of the PD-1/PDL1 axis augments lysis of AML cells by the CD33/CD3 BiTE antibody construct AMG 330: reversing a T-cell-induced immune escape mechanism. Leukemia 30(2): 484-491, 2016. PMID: 26239198. DOI: 10.1038/leu.2015.214

84 Heinhuis KM, Ros W, Kok M, Steeghs N, Beijnen JH and Schellens JHM: Enhancing antitumor response by combining immune checkpoint inhibitors with chemotherapy in solid tumors. Ann Oncol 30(2): 219-235, 2019. PMID: 30608567. DOI: $10.1093 /$ annonc/mdy551

85 Jiang $\mathrm{T}$, Zhou $\mathrm{C}, \mathrm{Hu} \mathrm{J}$ and Song Y: Combination immune checkpoint inhibitors with platinum-based chemotherapy in advanced non-small cell lung cancer: what's known and what's next. Transl Lung Cancer Res 8(Suppl 4): S447-S450, 2019. PMID: 32038935. DOI: 10.21037/tlcr.2019.11.10

86 West H, McCleod M, Hussein M, Morabito A, Rittmeyer A, Conter HJ, Kopp HG, Daniel D, McCune S, Mekhail T, Zer A, Reinmuth N, Sadiq A, Sandler A, Lin W, Ochi Lohmann T, Archer V, Wang L, Kowanetz $M$ and Cappuzzo F: Atezolizumab in combination with carboplatin plus nabpaclitaxel chemotherapy compared with chemotherapy alone as first-line treatment for metastatic non-squamous non-small-cell lung cancer (IMpower130): a multicentre, randomised, openlabel, phase 3 trial. Lancet Oncol 20(7): 924-937, 2019. PMID: 31122901. DOI: 10.1016/S1470-2045(19)30167-6

87 Gandhi L, Rodríguez-Abreu D, Gadgeel S, Esteban E, Felip E, De Angelis F, Domine M, Clingan P, Hochmair MJ, Powell SF, Cheng SY, Bischoff HG, Peled N, Grossi F, Jennens RR, Reck M, Hui R, Garon EB, Boyer M, Rubio-Viqueira B, Novello S, Kurata T, Gray JE, Vida J, Wei Z, Yang J, Raftopoulos H, Pietanza MC, Garassino MC and KEYNOTE-189 Investigators: Pembrolizumab plus chemotherapy in metastatic non-small-cell lung cancer. N Engl J Med 378(22): 2078-2092, 2018. PMID: 29658856. DOI: $10.1056 /$ NEJMoa 1801005

88 A(B)VD followed by nivolumab as frontline therapy for higher risk patients with classical Hodgkin lymphoma (HL) ClinicalTrials.gov. Available at: https://clinicaltrials.gov/ct2/show/ NCT03033914 [last accessed August 14, 2020]

89 Zeidner J, Vincent B, Ivanova A, Foster M, Coombs C, Jamieson K, Van deventer H, Blanchard L, Frank C, Gallagher S, Matson M, Pepin K, Vaught L, Vogler N, Miller K, Betts L, Mckinnon K, Bortone D, Parker J, Luznik L, Gojo I and Serody $\mathrm{J}$ : Genomics reveal potential biomarkers of response to pembrolizumab after high dose cytarabine in an ongoing phase II trial in relapsed/refractory aml. Blood 132(Suppl 1): 4054 4054, 2019. DOI: 10.1182/blood-2018-99-116608

90 Herrera AF, Moskowitz AJ, Bartlett NL, Vose JM, Ramchandren R, Feldman TA, LaCasce AS, Ansell SM, Moskowitz CH, Fenton K, Ogden CA, Taft D, Zhang Q, Kato $\mathrm{K}$, Campbell $\mathrm{M}$ and Advani RH: Interim results of brentuximab 
vedotin in combination with nivolumab in patients with relapsed or refractory Hodgkin lymphoma. Blood 131(11): 1183-1194, 2018. PMID: 29229594. DOI: 10.1182/blood-201710-811224

91 Diefenbach C, Hong F, Ambinder R, Cohen J, Robertson M, David K, Advani R, Fenske T, Barta S, Palmisano N, Svoboda J, Morgan D, Karmali R, Kahl B and Ansell S: A phase I study with an expansion cohort of the combinations of ipilimumab, nivolumab and brentuximab vedotin in patients with relapsed/refractory Hodgkin lymphoma: A trial of the ECOGACRIN research group (E4412: Arms G-I). Blood 132(Suppl 1): 679-679, 2019. DOI: 10.1182/blood-2018-99-115390

92 Yang H, Bueso-Ramos C, DiNardo C, Estecio MR, Davanlou M, Geng QR, Fang Z, Nguyen M, Pierce S, Wei Y, Parmar S, Cortes J, Kantarjian $\mathrm{H}$ and Garcia-Manero G: Expression of PD-L1, PD-L2, PD-1 and CTLA4 in myelodysplastic syndromes is enhanced by treatment with hypomethylating agents. Leukemia 28(6): 1280-1288, 2014. PMID: 24270737. DOI: $10.1038 /$ leu.2013.355

93 Wang H, Kaur G, Sankin A, Chen F, Guan F and Zang X: Immune checkpoint blockade and CAR-T cell therapy in hematologic malignancies. Journal of Hematology \& Oncology 12(1), 2020. DOI: 10.1186/s13045-019-0746-1

94 Yilmaz MT, Elmali A and Yazici G: Abscopal Effect, From Myth to Reality: From Radiation Oncologists' Perspective. Cureus 11(1): e3860, 2019. PMID: 30899611. DOI: 10.7759/cureus.3860

95 Friedman D, Baird JR, Young KH, Cottam B, Crittenden MR, Friedman S, Gough MJ and Newell P: Programmed cell death1 blockade enhances response to stereotactic radiation in an orthotopic murine model of hepatocellular carcinoma. Hepatol Res 47(7): 702-714, 2017. PMID: 27501850. DOI: 10.1111/hepr.12789

96 Dewan MZ, Galloway AE, Kawashima N, Dewyngaert JK, Babb JS, Formenti SC and Demaria S: Fractionated but not single-dose radiotherapy induces an immune-mediated abscopal effect when combined with anti-CTLA-4 antibody. Clin Cancer Res 15(17): 5379-88, 2009. PMID: 19706802. DOI: 10.1158/ 1078-0432.CCR-09-0265

97 Postow MA, Callahan MK, Barker CA, Yamada Y, Yuan J, Kitano S, Mu Z, Rasalan T, Adamow M, Ritter E, Sedrak C, Jungbluth AA, Chua R, Yang AS, Roman RA, Rosner S, Benson B, Allison JP, Lesokhin AM, Gnjatic S and Wolchok JD: Immunologic correlates of the abscopal effect in a patient with melanoma. N Engl J Med 366(10): 925-931, 2012. PMID: 22397654. DOI: 10.1056/NEJMoa1112824

98 Golden EB, Demaria S, Schiff PB, Chachoua A and Formenti SC: An abscopal response to radiation and ipilimumab in a patient with metastatic non-small cell lung cancer. Cancer Immunol Res 1(6): 365-372, 2013. PMID: 24563870. DOI: 10.1158/2326-6066.CIR-13-0115

99 Ehrlich P, Bolduan C and b: Collected studies on immunity. 2d ed. New York: J. Wiley \& Sons, 1912

100 Boyiadzis $\mathrm{M}$ and Foon KA: Approved monoclonal antibodies for cancer therapy. Expert Opin Biol Ther 8(8): 1151-1158, 2008. PMID: 18613766 . DOI: $10.1517 / 14712598.8 .8 .1151$

101 Brinkmann U and Kontermann RE: The making of bispecific antibodies. MAbs 9(2): 182-212, 2017. PMID: 28071970. DOI: 10.1080/19420862.2016.1268307

102 Felices M, Lenvik TR, Davis ZB, Miller JS and Vallera DA: Generation of BiKEs and TriKEs to improve NK cell-mediated targeting of tumor cells. Methods Mol Biol 1441: 333-346, 2016. PMID: 27177679. DOI: 10.1007/978-1-4939-3684-7_28

103 Wang Q, Chen Y, Park J, Liu X, Hu Y, Wang T, McFarland K and Betenbaugh MJ: Design and production of bispecific antibodies. Antibodies (Basel) 8(3), 2019. PMID: 31544849. DOI: 10.3390/antib8030043

104 Marayati R, Quinn C and Beierle E: Immunotherapy in pediatric solid tumors - A systematic review. Cancers 11(12): 2022, 2019. DOI: 10.3390/cancers 11122022

105 Yuraszeck T, Kasichayanula S and Benjamin J: Translation and clinical development of bispecific T-cell engaging antibodies for cancer treatment. Clinical Pharmacology \& Therapeutics 101(5): 634-645, 2020. DOI: 10.1002/cpt.651

106 Dreier T, Lorenczewski G, Brandl C, Hoffmann P, Syring U, Hanakam F, Kufer P, Riethmuller G, Bargou R and Baeuerle PA: Extremely potent, rapid and costimulation-independent cytotoxic T-cell response against lymphoma cells catalyzed by a single-chain bispecific antibody. Int J Cancer 100(6): 690697, 2002. PMID: 12209608. DOI: 10.1002/ijc.10557

107 Nagorsen D, Kufer P, Baeuerle PA and Bargou R: Blinatumomab: a historical perspective. Pharmacol Ther 136(3): 334-342, 2012. PMID: 22940266. DOI: 10.1016/j.pharmthera.2012.07.013

108 Hoffmann P, Hofmeister R, Brischwein K, Brandl C, Crommer S, Bargou R, Itin C, Prang N and Baeuerle PA: Serial killing of tumor cells by cytotoxic T cells redirected with a CD19-/CD3bispecific single-chain antibody construct. Int J Cancer 115(1): 98-104, 2005. PMID: 15688411. DOI: 10.1002/ijc.20908

109 Velasquez MP, Bonifant CL and Gottschalk S: Redirecting T cells to hematological malignancies with bispecific antibodies. Blood 131(1): 30-38, 2018. PMID: 29118005. DOI: 10.1182/blood-2017-06-741058

110 Dombret H, Topp MS, Schuh AC, Wei AH, Durrant S, Bacon CL, Tran Q, Zimmerman Z and Kantarjian H: Blinatumomab versus chemotherapy in first salvage or in later salvage for Bcell precursor acute lymphoblastic leukemia. Leuk Lymphoma 60(9): 2214-2222, 2019. PMID: 30947585. DOI: 10.1080/ 10428194.2019.1576872

111 Dombret H, Seymour JF, Butrym A, Wierzbowska A, Selleslag D, Jang JH, Kumar R, Cavenagh J, Schuh AC, Candoni A, Récher C, Sandhu I, Bernal del Castillo T, Al-Ali HK, Martinelli G, Falantes J, Noppeney R, Stone RM, Minden MD, McIntyre H, Songer S, Lucy LM, Beach CL and Döhner H: International phase 3 study of azacitidine vs conventional care regimens in older patients with newly diagnosed AML with $>30 \%$ blasts. Blood 126(3): 291-299, 2015. PMID: 25987659. DOI: $10.1182 /$ blood-2015-01-621664

112 Nisonoff A, Wissler FC and Lipman LN: Properties of the major component of a peptic digest of rabbit antibody. Science 132(3441): 1770-1771, 1960. PMID: 13729245. DOI: 10.1126/science.132.3441.1770

113 Fudenberg HH, Drews $G$ and Nisonoff A: Serologic demonstration of dual specificity of rabbit bivalent hybrid antibody. J Exp Med 119: 151-166, 1964. PMID: 14113110. DOI: $10.1084 /$ jem.119.1.151

114 Topp MS, Gökbuget N, Zugmaier G, Klappers P, Stelljes M, Neumann S, Viardot A, Marks R, Diedrich H, Faul C, Reichle A, Horst HA, Brüggemann M, Wessiepe D, Holland C, Alekar S, Mergen N, Einsele H, Hoelzer D and Bargou RC: Phase II trial of the anti-CD19 bispecific T cell-engager blinatumomab 
shows hematologic and molecular remissions in patients with relapsed or refractory B-precursor acute lymphoblastic leukemia. J Clin Oncol 32(36): 4134-4140, 2014. PMID: 25385737. DOI: $10.1200 /$ JCO.2014.56.3247

115 Kantarjian H, Stein A, Gökbuget N, Fielding AK, Schuh AC, Ribera JM, Wei A, Dombret H, Foà R, Bassan R, Arslan Ö, Sanz MA, Bergeron J, Demirkan F, Lech-Maranda E, Rambaldi A, Thomas X, Horst HA, Brüggemann M, Klapper W, Wood BL, Fleishman A, Nagorsen D, Holland C, Zimmerman Z and Topp MS: Blinatumomab versus chemotherapy for advanced acute lymphoblastic leukemia. N Engl J Med 376(9): 836-847, 2017. PMID: 28249141. DOI: 10.1056/NEJMoa1609783

116 Jen EY, Xu Q, Schetter A, Przepiorka D, Shen YL, Roscoe D, Sridhara R, Deisseroth A, Philip R, Farrell AT and Pazdur R: FDA Approval: Blinatumomab for patients with $\mathrm{b}$-cell precursor acute lymphoblastic leukemia in morphologic remission with minimal residual disease. Clin Cancer Res 25(2): 473-477, 2019. PMID: 30254079. DOI: 10.1158/1078-0432.CCR-182337

117 Gökbuget N, Zugmaier G, Klinger M, Kufer P, Stelljes M, Viardot A, Horst HA, Neumann S, Brüggemann M, Ottmann OG, Burmeister T, Wessiepe D, Topp MS and Bargou R: Longterm relapse-free survival in a phase 2 study of blinatumomab for the treatment of patients with minimal residual disease in B-lineage acute lymphoblastic leukemia. Haematologica 102(4): e132-e135, 2017. PMID: 28082340. DOI: 10.3324/haematol.2016.153957

118 Von stackelberg A, Locatelli F, Zugmaier G, Handgretinger R, Trippett T, Rizzari C, Bader P, O'brien M, Brethon B, Bhojwani D, Schlegel P, Borkhardt A, Rheingold S, Cooper T, Zwaan C, Barnette P, Messina C, Michel G, Dubois S, Hu K, Zhu M, Whitlock $J$ and Gore L: Phase I/phase II study of Blinatumomab in pediatric patients with relapsed/refractory acute lymphoblastic leukemia. Journal of Clinical Oncology 34(36): 4381-4389, 2020. DOI: 10.1200/JCO.2016.67.3301

119 An open-label, multicenter, phase I/IB trial evaluating the safety and pharmacokinetics of escalating doses of BTCT4465A as a single agent and combined with atezolizumab in patients with relapsed or refractory B-cell non-Hodgkin's lymphoma and chronic lymphocytic leukemia. ClinicalTrials.gov. Available at: https://clinicaltrials.gov/ct2/show/NCT02500407 [last accessed January 1, 2021]

120 Schuster S, Bartlett N, Assouline S, Yoon S, Bosch F, Sehn L, Cheah C, Shadman M, Gregory G, Ku M, Wei M, Yin S, Kwan A, Yousefi K, Hernandez G, Li C, O'hear C and Budde L: Mosunetuzumab induces complete remissions in poor prognosis non-Hodgkin lymphoma patients, including those who are resistant to or relapsing after chimeric antigen receptor T-Cell (CAR-T) therapies, and is active in treatment through multiple lines. Blood 134(Suppl_1): 6-6, 2020. DOI: 10.1182/blood-2019-123742

121 Löffler A, Kufer P, Lutterbüse R, Zettl F, Daniel PT, Schwenkenbecher JM, Riethmüller G, Dörken B and Bargou $\mathrm{RC}$ : A recombinant bispecific single-chain antibody, CD19 x CD3, induces rapid and high lymphoma-directed cytotoxicity by unstimulated T lymphocytes. Blood 95(6): 2098-2103, 2000. PMID: 10706880

122 Sedykh SE, Prinz VV, Buneva VN and Nevinsky GA: Bispecific antibodies: design, therapy, perspectives. Drug Des Devel Ther 12: 195-208, 2018. PMID: 29403265. DOI: 10.2147/DDDT.S151282
123 Budde L, Sehn L, Assouline S, Flinn I, Isufi I, Yoon S, Kim W, Matasar M, Nastoupil L, Santiago R, Koh Y, Hernandez G, Li C, Kulkarni P, Mccall B, Mcclellan S, Yin S, Gupta V, Chu Y and Bartlett N: Mosunetuzumab, a full-length bispecific CD20/CD3 antibody, displays clinical activity in relapsed/refractory B-cell non-Hodgkin lymphoma (NHL): Interim safety and efficacy results from a Phase 1 study. Blood 132(Suppl 1): 399-399, 2019. DOI: 10.1182/blood-2018-99-118344

124 Suryadevara CM, Gedeon PC, Sanchez-Perez L, Verla T, Alvarez-Breckenridge C, Choi BD, Fecci PE and Sampson JH: Are BiTEs the "missing link" in cancer therapy? Oncoimmunology 4(6): e1008339, 2015. PMID: 26155413. DOI: $10.1080 / 2162402 X .2015 .1008339$

125 Lee DW, Gardner R, Porter DL, Louis CU, Ahmed N, Jensen M, Grupp SA and Mackall CL: Current concepts in the diagnosis and management of cytokine release syndrome. Blood 124(2): 188-195, 2014. PMID: 24876563. DOI: 10.1182/blood-2014-05-552729

126 Teachey DT, Lacey SF, Shaw PA, Melenhorst JJ, Maude SL, Frey N, Pequignot E, Gonzalez VE, Chen F, Finklestein J, Barrett DM, Weiss SL, Fitzgerald JC, Berg RA, Aplenc R, Callahan C, Rheingold SR, Zheng Z, Rose-John S, White JC, Nazimuddin F, Wertheim G, Levine BL, June CH, Porter DL and Grupp SA: Identification of predictive biomarkers for cytokine release syndrome after chimeric antigen receptor Tcell therapy for acute lymphoblastic leukemia. Cancer Discov 6(6): 664-79, 2016. PMID: 27076371. DOI: 10.1158/21598290.CD-16-0040

127 Bargou R, Leo E, Zugmaier G, Klinger M, Goebeler M, Knop S, Noppeney R, Viardot A, Hess G, Schuler M, Einsele H, Brandl C, Wolf A, Kirchinger P, Klappers P, Schmidt M, Riethmüller G, Reinhardt C, Baeuerle PA and Kufer P: Tumor regression in cancer patients by very low doses of a $\mathrm{T}$ cellengaging antibody. Science 321(5891): 974-977, 2008. PMID: 18703743. DOI: $10.1126 /$ science. 1158545

128 Klinger M, Brandl C, Zugmaier G, Hijazi Y, Bargou RC, Topp MS, Gökbuget N, Neumann S, Goebeler M, Viardot A, Stelljes M, Brüggemann M, Hoelzer D, Degenhard E, Nagorsen D, Baeuerle PA, Wolf A and Kufer P: Immunopharmacologic response of patients with B-lineage acute lymphoblastic leukemia to continuous infusion of T cell-engaging CD19/CD3bispecific BiTE antibody blinatumomab. Blood 119(26): 62266233, 2012. PMID: 22592608. DOI: 10.1182/blood-2012-01400515

129 Topp MS, Gökbuget N, Zugmaier G, Degenhard E, Goebeler ME, Klinger M, Neumann SA, Horst HA, Raff T, Viardot A, Stelljes M, Schaich M, Köhne-Volland R, Brüggemann M, Ottmann OG, Burmeister T, Baeuerle PA, Nagorsen D, Schmidt M, Einsele H, Riethmüller G, Kneba M, Hoelzer D, Kufer P and Bargou RC: Long-term follow-up of hematologic relapsefree survival in a phase 2 study of blinatumomab in patients with MRD in B-lineage ALL. Blood 120(26): 5185-5187, 2012. PMID: 23024237. DOI: 10.1182/blood-2012-07-441030

130 Topp MS, Kufer P, Gökbuget N, Goebeler M, Klinger M, Neumann S, Horst HA, Raff T, Viardot A, Schmid M, Stelljes M, Schaich M, Degenhard E, Köhne-Volland R, Brüggemann M, Ottmann O, Pfeifer H, Burmeister T, Nagorsen D, Schmidt M, Lutterbuese R, Reinhardt C, Baeuerle PA, Kneba M, Einsele H, Riethmüller G, Hoelzer D, Zugmaier G and Bargou RC: Targeted therapy with the T-cell-engaging antibody 
blinatumomab of chemotherapy-refractory minimal residual disease in B-lineage acute lymphoblastic leukemia patients results in high response rate and prolonged leukemia-free survival. J Clin Oncol 29(18): 2493-2498, 2011. PMID: 21576633. DOI: $10.1200 / J C O .2010 .32 .7270$

131 Barrett DM, Teachey DT and Grupp SA: Toxicity management for patients receiving novel T-cell engaging therapies. Curr Opin Pediatr 26(1): 43-49, 2014. PMID: 24362408. DOI: 10.1097/MOP.0000000000000043

132 Nägele V, Kratzer A, Zugmaier G, Holland C, Hijazi Y, Topp MS, Gökbuget N, Baeuerle PA, Kufer P, Wolf A and Klinger M: Changes in clinical laboratory parameters and pharmacodynamic markers in response to blinatumomab treatment of patients with relapsed/refractory ALL. Exp Hematol Oncol 6: 14, 2017. PMID: 28533941. DOI: 10.1186/s40164-017-0074-5

133 Maude SL, Frey N, Shaw PA, Aplenc R, Barrett DM, Bunin NJ, Chew A, Gonzalez VE, Zheng Z, Lacey SF, Mahnke YD, Melenhorst JJ, Rheingold SR, Shen A, Teachey DT, Levine BL, June $\mathrm{CH}$, Porter DL and Grupp SA: Chimeric antigen receptor $\mathrm{T}$ cells for sustained remissions in leukemia. N Engl J Med 371(16): 1507-1517, 2014. PMID: 25317870. DOI: 10.1056/NEJMoa1407222

134 Teachey DT, Rheingold SR, Maude SL, Zugmaier G, Barrett DM, Seif AE, Nichols KE, Suppa EK, Kalos M, Berg RA, Fitzgerald JC, Aplenc R, Gore L and Grupp SA: Cytokine release syndrome after blinatumomab treatment related to abnormal macrophage activation and ameliorated with cytokine-directed therapy. Blood 121(26): 5154-5157, 2013. PMID: 23678006. DOI: 10.1182/blood-2013-02-485623

135 Klinger M, Zugmaier G, Naegele V, Goebeler M, Brandl C, Bargou R and Kufer P: Pathogenesis-based development of potential mitigation strategies for blinatumomab-associated neurologic events (NEs). Blood 128(22): 1589-1589, 2019. DOI: 10.1182/blood.V128.22.1589.1589

136 Gökbuget N, Dombret H, Bonifacio M, Reichle A, Graux C, Faul C, Diedrich H, Topp MS, Brüggemann M, Horst HA, Havelange V, Stieglmaier J, Wessels H, Haddad V, Benjamin JE, Zugmaier G, Nagorsen D and Bargou RC: Blinatumomab for minimal residual disease in adults with B-cell precursor acute lymphoblastic leukemia. Blood 131(14): 1522-1531, 2018. PMID: 29358182. DOI: 10.1182/blood-2017-08-798322

137 Zoghbi A, Zur Stadt U, Winkler B, Müller I and Escherich G: Lineage switch under blinatumomab treatment of relapsed common acute lymphoblastic leukemia without MLL rearrangement. Pediatr Blood Cancer 64(11), 2017. PMID: 28453885. DOI: $10.1002 / \mathrm{pbc} .26594$
138 Curran E and Stock W: Taking a "BiTE out of ALL": blinatumomab approval for MRD-positive ALL. Blood 133(16): 1715-1719, 2019. PMID: 30796026. DOI: 10.1182/blood-2018$12-852376$

139 Aldoss I, Song J, Stiller T, Nguyen T, Palmer J, O'donnell M, Stein A, Marcucci G, Forman S and Pullarkat V: Correlates of resistance and relapse during blinatumomab therapy for relapsed/refractory acute lymphoblastic leukemia. American Journal of Hematology 92(9): 858-865，2019. DOI: 10.1002/ajh.24783

140 Sotillo E, Barrett DM, Black KL, Bagashev A, Oldridge D, Wu G, Sussman R, Lanauze C, Ruella M, Gazzara MR, Martinez NM, Harrington CT, Chung EY, Perazzelli J, Hofmann TJ, Maude SL, Raman P, Barrera A, Gill S, Lacey SF, Melenhorst JJ, Allman D, Jacoby E, Fry T, Mackall C, Barash Y, Lynch KW, Maris JM, Grupp SA and Thomas-Tikhonenko A: Convergence of Acquired Mutations and Alternative Splicing of CD19 Enables Resistance to CART-19 Immunotherapy. Cancer Discov 5(12): 1282-1295, 2015. PMID: 26516065. DOI: $10.1158 / 2159-8290 . C D-15-1020$

$141 \mathrm{Ha}$ JH, Kim JE and Kim YS: Immunoglobulin Fc Heterodimer Platform Technology: From design to applications in therapeutic antibodies and proteins. Front Immunol 7: 394, 2016. PMID: 27766096. DOI: 10.3389/fimmu.2016.00394

142 Spiess C, Zhai Q and Carter P: Alternative molecular formats and therapeutic applications for bispecific antibodies. Molecular Immunology 67(2): 95-106, 2020. DOI: 10.1016/j.molimm. 2015.01 .003

143 Godar M, de Haard H, Blanchetot C and Rasser J: Therapeutic bispecific antibody formats: a patent applications review (19942017). Expert Opin Ther Pat 28(3): 251-276, 2018. PMID: 29366356. DOI: $10.1080 / 13543776.2018 .1428307$

144 Johnson S, Burke S, Huang L, Gorlatov S, Li H, Wang W, Zhang W, Tuaillon N, Rainey J, Barat B, Yang Y, Jin L, Ciccarone V, Moore PA, Koenig S and Bonvini E: Effector cell recruitment with novel Fv-based dual-affinity re-targeting protein leads to potent tumor cytolysis and in vivo B-cell depletion. J Mol Biol 399(3): 436-449, 2010. PMID: 20382161. DOI: $10.1016 /$ j.jmb.2010.04.001

145 Rader C: DARTs take aim at BiTEs. Blood 117(17): 4403-4404, 2019. DOI: 10.1182/blood-2011-02-337691

Received January 7, 2021

Revised February 5, 2021

Accepted February 9, 2021 